\title{
'Remixing Rasmussen’: The Evolution of Accimaps within Systemic Accident
} Analysis

\author{
Patrick Waterson ${ }^{1}$, Daniel P. Jenkins ${ }^{2}$, Paul M. Salmon ${ }^{3}$ and Peter Underwood ${ }^{4}$ \\ ${ }^{1}$ Human Factors and Complex Systems Group, \\ Loughborough University Design School, \\ Loughborough University, \\ Loughborough, LE11 3TU, \\ United Kingdom. \\ ${ }^{2}$ DCA Design International Ltd., \\ 19 Church Street, Warwick CV34 4AB, \\ United Kingdom. \\ ${ }^{3}$ University of the Sunshine Coast Accident Research, \\ University of the Sunshine Coast, \\ Locked Bag 4, Maroochydore DC, QLD 4558, \\ Australia. \\ ${ }^{4}$ Bunnyfoot, Harwell Innovation Centre \\ 173 Curie Avenue, Harwell, Oxfordshire, \\ OX11 0QG, United Kingdom.
}

\section{Address for correspondence:}

Dr. Patrick Waterson,

Human Factors and Complex Systems Group, Loughborough University Design School, Loughborough University, Loughborough, LE11 3TU, United Kingdom.

Tel: 01509228478

Fax: 01509223940

${ }^{1}$ Email: p.waterson@lboro.ac.uk 


\title{
'Remixing Rasmussen’: The Evolution of Accimaps within Systemic Accident Analysis
}

\begin{abstract}
Throughout Jens Rasmussen's career there has been a continued emphasis on the development of methods, techniques and tools for accident analysis and investigation. In this paper we focus on the evolution and development of one specific example, namely Accimaps and their use for accident analysis. We describe the origins of Accimaps followed by a review of 26 studies which have applied and adapted Accimaps over the period 200-2015 to a range of domains and types of accident. Aside from demonstrating the versatility and popularity of the method, part of the motivation for the review of the use of Accimaps is to address the question of what constitutes a sound, usable, valid and reliable approach to systemic accident analysis. The findings from the review demonstrate continuity with the work carried out by Rasmussen, as well as significant variation (e.g., changes to the Accimap, used of additional theoretical and practice-oriented perspectives on safety). We conclude the paper with some speculations regarding future extension and adaptation of the Accimap approach including the possibility of using hybrid models for accident analysis.
\end{abstract}

Keywords: Accident analysis and investigation, sociotechnical systems, Accimaps, organisational design, Jens Rasmussen. 


\section{Introduction}

During the 1980's and 1990's a series of high-profile accidents including Chernobyl (1986), Zeebrugge (1987), Challenger (1986) and Ladbroke Grove (1999) prompted researchers within the fields of human factors and safety science to move away from accounts of human error based solely around individual factors and to place more emphasis on the role played by human and organisational influences on safety. Hale and Hovden (1998) characterize the goals of what they termed the 'third age' of safety, as the achievement of a better understanding of the management issues, particularly in terms of safety 'culture' and 'climate' (Zohar, 1980; Antonsen, 2009). This shift of emphasis from 'micro' to 'macro' accounts of error (Le Coze, submitted) is reflected in the types of methods for accident analysis and investigation which developed from the 1980's up until the present day. These methods in themselves derive from a number of traditions including systems and macroergonomics (Hendrick and Kleiner, 2002; Wilson, 2014), safety engineering (Hollnagel, 2004) and cognitive systems engineering (Rasmussen, Pejtersen and Goodstein, 1994).

Figure 1 about here

More recent developments such as the growth of the internet, social media and globalisation, have introduced new forms of systemic risk into complex sociotechnical systems (e.g., security, financial and environmental risks - Goldin and Mariathasan, 2014) and are reflected in a later generation of accident analysis tools and methods (e.g., Systems-Theoretic Accident Model (STAMP) - Leveson, 2012; Functional Resonance Analysis Method (FRAM) - Hollnagel, 2012) which draw on sociotechnical systems theory, as well as the work which was conducted at the Risø Nuclear Plant by Jens Rasmussen and others from the late 1960’s up until 2000 (figure 1). 


\subsection{Rasmussen and Systemic Accident Analysis (SAA)}

The work of Jens Rasmussen and his colleagues was very much at the forefront of the new view of error which emphasised the role played by organisational and wider environmental and political factors in accident causation. In a paper summarising a workshop held at the World Bank in October, 1988 to discuss risk management in the wake of the late 1980's financial crisis (Rasmussen and Batstone, 1989), he emphasised the fact that technological and societal developments along with increasing competitive and commercial pressures on companies, had raised the potential for major accidents to occur. He also emphasised that part of the challenge involved in combating these pressures was the need for an expanded account of human behaviour which was sensitive to organisational and cultural context:

“... the human factors specialists are challenged to expand their vision beyond the confines of human error and reliability analysis and to explore ways in which they could link with the cognitive, decision, systems and organizational specialists in developing risk profiles of organizational and management systems in different regulatory and cultural environments (page iii) ... The rapid trend in the technological development now calls for a fresh view on risk management and safety control in large-scale hazardous systems (p. 39)... (Rasmussen and Batstone, 1989).

This emphasis was repeated a number of times in subsequent publications in the 1990's, for example, in the much cited paper which introduced the risk management framework (Rasmussen, 1997). The paper also included Rasmussen's dynamic model of safety, the purpose of which was to demonstrate how economic considerations and workload pressures can move the system away from safe performance and closer to the margin of error (figure 2):

"We need more studies of the vertical interaction among levels of socio-technical systems with reference to the nature of the technological hazard they are assumed to control.” (Rasmussen 1997, p. 187). 
Figure 2 about here

These ideas were incorporated into the Accimap method which was subsequently developed by Rasmussen and Inge Svedung in the late 1990's and early 2000's (Rasmussen, 1997; Rasmussen and Svedung, 2000; Svedung and Rasmussen, 2000). Accimaps attempt to model the dynamic interaction between multiple sociotechnical levels (regulatory, organisational, workplace) and account for the role these play in shaping the course of an accident as it happens over time. The use of Accimaps to provide insight into accidents and human error has grown in the last few years and a number of papers have applied the method to a wide variety of safety domains (e.g., public health - Vicente and Christoffersen, 2006; oil and gas industries - Hopkins, 2000; aerospace - Johnson and de Almeida, 2008). Figure 3 (a) shows a graph of the number of citations of Rasmussen (1997) starting form the first year in which it received a citation (2000). Figure 3 (b) shows a similar graph of citations for Rasmussen and Svedung (2000). Recent interest in Accimaps and other aspects of Rasmussen's approach to safety and risk management is demonstrated by the fact that in 2014 the 1997 paper received its highest number of citations relative to other years $(n=84)$. Aside from the academic community, Accimaps are also used for accident analysis and human factors training within a number of organisational contexts (e.g., the UK's Rail Safety and Standards Board, Royal Australian Air Force - Branford, 2010).

Figures 3 (a) and (b) about here

\subsection{Aims and objectives of the paper}

In this paper we consider the how Accimaps and their use have evolved over the last decade and a half and how they have been used by other researchers. The paper partly came about as the result of the authors using Accimaps in order to analyse safety across a variety of different application areas (e.g., Healthcare, Policing and 
Transport). Another aim was to provide details of part of the later period of Rasmussen's career (following on from other accounts which focus on his early work - e.g., Green, 1988; Sanderson and Harwood, 1988; Vicente, 2001). The specific objectives of the paper are:

- To carry out a review of studies which have used Accimaps for systemic accident analysis over the period 2000-2015 and is based on a framework which considers aspects of the theoretical and practical of using Accimaps (e.g., theoretical background to the study, aspects of the procedure used to build the Accimap; changes to the original format of the Accimap);

- To consider the outcomes from the review in terms of what it illustrates about the theory and practice of Systemic Accident Analysis (SAA) and the legacy of Jens Rasmussen.

\section{The origins of the Accimap}

In this section we first describe the format and content of the original version of the Accimap as outlined in Rasmussen (1997) and Svedung and Rasmussen (2000). We trace back the origins to two components or 'building blocks' from earlier work namely the 'abstraction hierarchy' and 'decision ladder'and the influence of ideas from control theory and engineering.

\subsection{Accimap format and content}

Accimaps typically focus on failures across six levels of analysis: government policy and budgeting; regulatory bodies and associations; local area government planning \& budgeting (including company management, technical and operational management); physical processes and actor activities; and equipment and surroundings. According to Rasmussen (1997) each systemic level is involved in safety management via the control of hazardous processes through laws, rules, and instructions. For systems to function safely decisions made at high levels should promulgate down and be reflected in the decisions and actions occurring at lower levels of the system. Conversely, information at the lower levels (e.g. staff, work, equipment) regarding the system's status needs to transfer up the hierarchy to 
inform the decisions and actions occurring at the higher levels. Without this so called 'vertical integration', systems can lose control of the processes that they are designed to control (Cassano-Piche et al., 2009). Rasmussen (1997) argues that accidents are typically 'waiting for release' (p. 190); the stage being set by the routine work practices of various actors working within the system. Normal variation in behaviour then serves to release accidents. The risk management framework and Accimap method are shown in Figures 4 and 5.

Figures 4 and 5 about here

It is worthwhile noting that Rasmussen (1997; Svedung and Rasmussen, 2000) describe a set of sub-components within the overall Accimap - the Actormap, Infomap and Conflict Map). Actormaps provide 'a layout of the decision-makers, planners, and actors who have been involved in the preparation of accidental conditions' (Svedung and Rasmussen, 2000, p. 18). The intention behind Infomaps is to show lines of strong and weak communication within an organization. Finally, Conflict Maps illustrate potential conflicts and tensions between actors that might have contributed to the preconditions for the incident (de Almeida and Johnson, 2008).

\subsection{Accimaps, the 'abstraction hierarchy' and 'decision ladder'}

Looking through the publications and reports produced by Rasmussen dating back to 1968 provides a number of insights into the origins and subsequent development of Accimaps. As Cook (2014) points out, Rasmussen was a very visual thinker whose work was shaped by his training in electronics and engineering (see also Vicente, 2001 for an explanation of Rasmussen's background on his subsequent work on human error). The various papers and Risø reports produced by Rasmussen and colleagues are frequently illustrated by a variety of engineering diagrams, drawings and other graphical material. Some of this material shows signs of some of earliest stages in the development of the risk management framework and Accimaps. Figure 6 for example is an early attempt (1974) to describe the 
'abstraction hierarchy' (Rasmussen and Vicente, 1989) or 'decision ladder' (Rasmussen, 1986). Each successive rung in the ladder represents the mental operations of the operator as they move from assessing the current system state (e.g., a control room interface) towards the target state to be achieved. A similar hierarchy (figure 7) is described in another paper (Rasmussen, 1987) where the focus is on the interaction between physiological and psychological factors and their combined role in contributing toward human error. In comparing figures 6 and 7 it seems not unreasonable to speculate that Rasmussen was gradually shifting the emphasis in his work on human error further 'upwards' in the hierarchy and moving toward an account of the influence of managerial and wider organisational factors in accident causation. A movement that was taken further and integrated into his work on the risk management framework and Accimaps through the inclusion of political, economic and regulatory factors (figure 4).

Figures 6 and 7 about here

\subsection{The influence of control theory}

Rasmussen's work involved consulting a wide range of sources and evidence of reading across a large range of disciplines within the physical, engineering and social sciences. Le Coze (submitted) similarly argues that much of his work demonstrated the influence of thinking based on cybernetics and the work of Norbert Wiener and William Ross Ashby amongst others (e.g., mechanisms for system feedforward and feedback). Leveson (submitted) also points to the influence of control theory on his research from the 1960's onwards. The Accimap was designed to take a control theory-based systems thinking approach to accident analysis. Consequently, accidents are considered to result from the loss of control over potentially harmful physical processes. According to Rasmussen (1997), every organisational level in a system affects the control of these hazards and a vertically integrated view of system behaviour is required. The dynamic nature of sociotechnical systems means that an accident is likely to be prepared over time by the 
normal efforts of many individuals throughout a system and that a normal variation in somebody's behaviour can 'release' an accident:

"The propagation of an accidental course of events is shaped by the activity of people that either can trigger an accidental flow of events or divert a normal flow. Safety, then, depends on the control of work processes so as to avoid accidental side effects causing harm to people, environment, or investment"(Rasmussen and Svedung, 2000, p.9)

Figure 8 (Rasmussen, 1968) shows an example of the use of a box and arrow diagram to describe the interaction between the operator and the instrumentation within a process plant. Similarly, figure 9 (Rasmussen, 1980) illustrates a model of the human operator in a control system which incorporates more sophisticated aspects of the information processing. It is interesting to draw parallels between these box-model control flow diagrams and the arrangement of causal factors, preconditions and consequences which contribute towards an accident and make up part of the Accimap diagram (figure 4). Rasmussen's earlier work within control theory and the abstraction hierarchy/decision ladder appear to be integrated in subsequent research and accident analysis in the late 1990's and early 2000's.

Figures 8 and 9 about here

\section{Recent research using Accimaps}

\subsection{Search strategy}

In order to identify recent studies which have used Accimaps to analyse large-scale, complex accidents, we adopted a strategy of working backwards from the scientific published literature (e.g., within bibliometric databases), as well as looking at articles citing the original publications and reports by Rasmussen which relate to Accimaps (i.e., Rasmussen, 1997; Rasmussen and Svedung, 2000; Svedung and Rasmussen, 2002). The search covered the period 2000-2015 and was conducted in June 2015. A final method of locating studies was to compare our own personal lists 
of studies and to discuss our literature amongst ourselves (all four authors have been active Accimap users over the last few years). We also contacted and gathered information from other researchers who had used and published papers in the last decade or so. Four databases were searched using the term 'Accimap*' and variations of the form of the word (e.g., AcciMap, ACCIMAP), these were: the ISI Web of Science; Google Scholar, Ergonomics Abstracts and PsycINFO.

\subsection{A framework for analysing and comparing the use of Accimaps}

In order to cover both the theoretical implications of using Accimaps and details of practical concerns (e.g., how they were constructed), we used 10 separate categories in order to compare studies, these covered: the context in which the Accimap was used (e.g., healthcare, transport, aviation); the goals and objectives of the study (e.g., providing a systemic account of the factors contributing to the accident); the theoretical background of the study (e.g., sociotechnical systems theory); the procedure described in building the Accimap (e.g., use of two or more analysts; use of thematic coding or other qualitative data analysis methods); the outcomes from the analysis (e.g., type of Accimap); comparisons with other models (e.g., with HFACS, STAMP); levels of analysis (i.e., number and type of levels used); casual factors (i.e., number); changes to the standard Accimap (i.e., major/minor deviations from the format of the Accimaps described in Rasmussen and Svedung, 2000); and, other details (i.e., any other noteworthy or idiosyncratic features of the analysis).

\section{Findings}

\subsection{Recent research using Accimaps}

Table 1 shows the results of searching though the four databases. We removed duplicates and studies which did not report in details using Accimaps to carry out an analysis of an accident (e.g., Branford et al., 2009 where guidelines for the use of Accimaps are described; Salmon et al., 2012 where a high-level illustration of the application of Accimaps to road transport is presented) and studies which reported using the Accimap in two or more publications (e.g., in a journal article and conference presentation). The final sample comprised 26 studies. Table 2 lists the authors and titles of these studies. Appendix 1 contains a list of the studies and their publication details. 
Tables 1 and 2 about here

\subsection{Applying the framework}

Table 3 is a summary of the results of applying the framework described in section 3.2 to the 26 studies. In subsequent sections (4.2.1 to 4.2.5) of the paper, we refer to individual studies with reference to their numbering in table 2 (e.g., study 2 is Woo and Vicente, 2005).

Table 3 about here

\subsubsection{Context of use}

A total of 10 separate domains are covered by the studies: Manufacturing (12); Nuclear (13); Aviation and Aerospace (5, 14, 16, 21 and 23) ; Emergency Response (22); Civil Engineering (25); Oil and Gas (1, 24); Public Health (2, 6, and 7); Transport (Rail - 3, 17, 18, 26 and Road - 21 and 26); Outdoor Recreation (8, 9); and Policing and Security $(10,11)$. The most frequent use of Accimaps occurs in Aviation and Aerospace (5 studies), Transport (Rail - 4 studies), and Public Health (3 studies).

\subsubsection{Study goals and objectives and theoretical background}

Most of the papers stated that their overall goal was to analyse a complex sociotechnical system and understand the role played by a range of contributory factors in causing an accident to occur. Within this broad category, Accimaps were sometimes used to underline specific aspects and advantages of adopting and applying a systems approach towards accident analysis. For example, studies mentioned the value of Accimaps in terms of their ability to apply a 'holistic' (13), 'big picture' (14), 'system of systems' (24) viewpoint or approach towards accidents. The use of a set of predictions set out by Rasmussen (1997) concerning the risk management framework (e.g., 'Safety as an emergent property of a complex socio-technical system') was employed in order to test the explanatory adequacy of 
the framework for specific domains (e.g., Public Health - 4, 6; Policing and Security - 10; emergency response - 22; Accidents involving young drivers - 26). Other papers placed emphasis on the value of using Accimaps to probe deeper into the 'causal networks' (1), 'interdependencies' (10) and general system-wide failures (24) within complex sociotechnical systems. Accimaps were also used in order to highlight the role played by specific systemic features of accidents which are sometimes underplayed or neglected by other accident analysis techniques (e.g., organisational factors $-7,16$; the dynamic interplay between individual cognition, decision-making and motivation in accident scenarios - 10, 11, 16, and 26). Finally, a few studies compared the outcomes from an Accimap analysis with other accident analysis methods (e.g., Root Cause Analysis - 8; STAMP - 9, 18; Australian Transportation Safety Board (ATSB) Model - 18; HFACS - 9).

The theoretical stance adopted by most studies corresponded to Rasmussen's (1997; figure 2) model of the boundaries of acceptable and unacceptable performance within sociotechnical systems. It is also clear that the studies drawn on a diverse range of disciplines and theoretical traditions in their use of Accimaps, these include: theory oriented around high reliability organisations (Weick and Sutcliffe, 2007) - 1; Normal Accident Theory (Perrow, 1984 - 23); schema theory (Neisser, 1976) - 10, 11 and 16; and, organisational sociology - 1 (Turner, 1978); as well as disciplines such as computer science and logic - 3, safety science and safety engineering - 5, 12, 24 and 25, and human factors, cognitive ergonomics and general engineering - 10, 11, 17, 13 and 20).

\subsubsection{Procedure and outcomes}

The relative unconstrained manner in which Accimaps are constructed has led a number of authors to raise questions concerning the reliability and validity of Accimaps (e.g., Johnson and de Almeida, 2008; Branford, 2007; Branford et al., 2009; Waterson and Jenkins, 2010, 2011). For this reason we examined the procedure which was used to construct Accimaps across the 26 studies (e.g., the use of coding to identify causal contributory factors; procedures for reviewing the Accimap). Just over half of the studies in the sample (15) did not provide details of the procedure that was used to construct the Accimap. The most common procedure followed was for one or more of the study authors to carry out an initial analysis of 
the accident and then to present the Accimap for review by other co-authors or analysts $(8,9.10,11,16,17,20,22,25)$. In other cases, subject matter or domain experts (e.g., outdoor activity instructors; experts in rail safety) reviewed the Accimaps and suggested some modifications and revisions (9, 16 and 22). In two studies, the method used for qualitative analysis was described in detail (e.g., thematic analysis - Braun and Clarke, 2006 - 24, 25). In other cases explicit detail was provided of the stages in which the Accimap was constructed (e.g., 7, 12).

A range of different outcomes came about from using Accimaps. Some studies for example, use a combination of Accimap, Actormap and Conflict Map in order to describe the accident (2, 5 and 6). In other cases, the Accimap and Actormaps were used to capture causal factors, as well as possible countermeasures which could be put in place to prevent the accident happening again (18). Study 25 involved the use of an aggregate Accimap in order to summarise contributory factors leading to accidents involving young drivers, as well as possible countermeasures. A more common approach was to use the Accimap in combination with another method or accident model (e.g., Why-Because Analysis - Ladkin and Loer, 2008 - 3; Root Cause Analysis - 8; HFACS and STAMP - 9; the Swiss Cheese Model - 15). Many studies provided additional annotation or detail to the basic format of the Accimap (e.g., annotating causal and cross-level relationships - 7, 10; integrating a timeline with the Accimap - 10,11, representing subsystems in a system-of-systems - 22), as well as using other techniques to provide additional analytical power to the accident analysis (e.g., the use of CWA - 11; Neisser's perceptual cycle - 11, 16). In two studies, the Accimap was used as a basis with which to construct a new model or method (e.g., the AcciTree method which combines Accimaps with a taxonomy based on HFACS - 19; 'Impromaps' which focus on accidents caused by operator improvisation - 20).

\subsubsection{Levels of analysis, causal factors, changes and other details}

Most studies did not deviate from the standard six levels of analysis as described by Rasmussen (1997). Where there were variations, these tended to be in cases where there was a need to re-label the levels to fit a specific context or application domain (e.g., Hospital management - 7; pedestrian level - 29). The average number of Accimap casual factors described in the study sample, excluding Actormaps and 
Conflict maps, was 38. The number of Accimap causal factors ranged from 7-71 and reflects that some studies presented a simplified overview of the accident (e.g., 1), whereas other went into more details and attempted to describe the complex interdependencies which existed between causal factors (e.g., 10, 11). The number of causal factors and level of detail in the Accimap is related to the goals and objectives of the study (section 4.2.2) - some studies (e.g., 1) presenting an overview of the accident, whilst others $(10,11)$ providing a very detailed, minuteby-minute account of how the accident unfolded across a range of stakeholders. Two studies added 'fault trees' or 'logic gates' to the Accimap (2 and 5), whilst other minor changes were made to the original format in order to accommodate testing of Rasmussen's predictions $(6,8)$ and formulating a set of cross-level hypotheses (e.g., the interaction between organisational and group levels of analysis - Karsh et al., 2014, study 7).

\section{Discussion}

\section{1 'Remixing Rasmussen’}

The 26 studies in tables 2 and 3 share a great deal in common with the original formulation of the Accimap as set out by Rasmussen in the late 1990's and early 2000's. Many of them draw on the dynamic model of safety and system performance (figure 2), as well as other theoretical aspects of the risk management framework (e.g., testing the predictions set out by the framework). Most of the studies also preserve the core Accimap 'building blocks' (section 2; e.g., levels of analysis; layout of causal factors). However, there is also large variation across the studies and these provide some insights into the ways in which the various researchers have been inspired by Rasmussen's work. Some of these variations might be said to reflect the way in which Rasmussen's work on the Accimap has been 'remixed', reinterpreted and evolved over the last few decades. In this section we focus on two aspects of this evolution or 'remixing' process which relate to the theoretical and practical aspects of systemic accident analysis.

5.1.1 Systemic accident analysis: 'rhetorical' aspects of Accimap usage and theory elaboration 
All of the studies in the sample aimed to provide a systemic account of factors which contribute towards accidents. Part of this involves emphasising that accidents do not come about as a result of single failures, but are attributable to a range of causal factors distributed across various part of the larger system. Despite the popularity of this view amongst the research community, single-factor explanations often prevail (Dekker et al., 2011). Part of the motivation in using Accimaps might therefore be said to be rhetorical: the Accimap provides a means with which to counter this view and to act as a demonstration of the value of adopting a systems perspective on human error, particularly in domains where the 'bad apply' theory of accidents (Dekker, 2014; Jun et al., submitted) continues to persist (e.g., aviation Holden, 2009; study 15). This is especially important in new areas of application where application of the system approach has little precedence (e.g., studies 2, 4, 6, $7,8,10,11,21)$. In recent and as yet unpublished work, for example, we have used Accimaps as a means to demonstrate the complexity of accident causation in public safety (food safety) and maritime accidents (shipping collisions - Nayak and Waterson, in preparation; Murray et al., submitted). One of the reasons for doing this was to counter overly-reductionist, person-centred accounts of accident causation in these domains (see for example Pennington, 2003 for an account of how this applies within food safety).

A second goal of systemic accident analysis is to probe deeper into interrelationships and causality across system levels. The use of Accimaps in study 11 for example, alongside other elements of Rasmussen's work (e.g., the decision ladder) attempted to integrate cognitive factors at the group level of analysis with a second set of factors related to individual decision-making. A similar desire to understand the causal inter-relationships between different levels of analysis was part of the motivation for using Accimaps in Waterson (2009, study 7). In this case, the analysis began as an attempt to underline the importance of the role of organisational factors in hospital infection control - one use of Accimaps which is common to a number of studies (e.g., 12 and 15). However, subsequent analysis using Accimaps facilitated the incorporation of theory drawn from organisational behaviour (in this case the co-called 'meso-paradigm' - House et al., 1995), alongside a set of multi-level hypotheses. The use of Accimaps in these and other studies, helped to clarify theoretical aspects of systemic accident analysis, as well as 
identify gaps in our understanding of the relationship between micro and macro systems components. How far we can go with multi-causal explanations is the subject of some debate (e.g., Reason, 1999; Shorrock et al., 2004), however, it is clear that one 'spin-off' from the use of Accimaps is that they help the analyst to develop new insights into the complex causal inter-relationships involved in accidents.

In general, an important characteristic of the evolution of Accimaps since their original formulation has been their use to elaborate and articulate new directions for theory within accident analysis. Part of this has come about because Accimaps focus on providing a systemic overview, as well as an examination of causal interrelationships. The process of constructing the Accimap might be said to be akin to accident 'sensemaking' (Weick, 1995) in that understanding and mapping causal factors within the Accimap often involves unravelling, or at least hypothesising, relationships across and between a wide range of levels of analysis within the overall system in question. Working through the Accimap helps to resolve ambiguities, as well as identifying new hypotheses and areas for further investigation (e.g., links with individual cognition, motivation, group attitudes studies, 10, 11, 16 and 26). Vaughan (1992, p.175-6) in her account of the process of understanding the causes of the Space Shuttle Challenger Accident describes a similar process in her description of what she calls 'case analysis':

"Because of the different sorts of data available from micro- and macro-level analysis, choosing cases that vary both the unit of analysis and the level of analysis, when possible, can lead to the elaboration of theory that more fully merges microand macro- understandings. Third, this method can be particularly advantageous for elaborating theories, models, and concepts focusing on large, complex systems that are difficult to study"

It might well be argued that this process of theory elaboration is common to all methods and model of accident analysis (figure 1). The key difference between these methods and models, however, is that in terms of procedure Accimaps are relatively unconstrained and are not intended to be used in a prescriptive, 'topdown' manner. The freedom afforded by Accimaps allows the analyst to explore a 
range of options for analysis and encourages experimentation and exploration of explanations which draw on the systems approach and systems theory. Rasmussen (1999, p. xi) made the following comment about Cognitive Work Analysis (CWA) and much the same philosophy might be said to apply to Accimaps:

"the CWA framework is not a prescriptive method ... it is a point of view, a state of mind, and a demonstration of the various dimensions of the problem of analysing work performance in a dynamic society”

\subsubsection{Practical trade-offs: validity, reliability and utility}

The extent to which models, methods and tools for systemic accident analysis produce outcomes which are valid (e.g., the degree to which the Accimap analysis successfully identifies the causes of an accident) and reliable (e.g., the degree to which accident analysts produce similar Accimaps) are often viewed as an important criteria for judging their appropriateness for accident analysis. For example, in discussing general human factors and ergonomics methods, Baber and Stanton (2002, p. 218) suggest that "there seems little point in employing a method that does not pass even the basic requirements of validity and reliability”. Likewise, Kanis (2014) argues that many methods in human factors and ergonomics fail to achieve acceptable levels of reliability and validity when used by both researchers and practitioners. More recently, Ryan (2015) included issues of reliability and validity in a list of eight requirements for methods for accident investigation and analysis.

Table 4 about here

Accimaps appear to meet the first seven requirements in table 4; however, across the 26 studies in the sample there are good reasons for questioning the degree to which they produce reliable and valid outcomes. The majority of studies for example, report very few details of how the Accimap was constructed. In other 
cases, the use of multiple coders/analysts and validation with domain experts might provide some degree of confidence that a degree of reliability and validity can be achieved by following the right procedure. Branford (2007) has carried out a very the detailed set of studies of the reliability and validity of Accimaps. She concluded that Accimap analyses do not always correctly identify the causes of accidents or the most appropriate corrective actions to prevent their recurrence. In order partly to improve on the validity and reliability, Branford et al., (2009) produced a set of nine guidelines covering construction of the Accimap. These guidelines provide a set of steps and prompts for analysts and are a considerable improvement on the limited information available in Rasmussen (1997; Rasmussen and Svedung, 2000).

Questions concerning the reliability and validity of human factors and accident analysis methods are often raised in conjunction with similar concerns about usability (i.e., how easy if the model, method etc. to use) and utility (how useful are the outcomes regardless of, for example, issues of validity and reliability). In some ways, the chief virtue of the Accimap is that it is relatively easy to use. As one participant at the Rasmussen Legacy symposium held in 2014 at Risø commented: "it's easy for practitioners to quickly get going with an Accimap, furthermore they understand it straight away". The experience of the authors of this paper is that the graphical representations produced by Accimaps also make them very suitable for communicating with audiences from backgrounds and specialisms outside of human factors. This is reinforced by other research comparing various system accident analysis methods and models and assessing the degree to which safety specialists and other practitioners are met by current systemic accident methods and models (Underwood and Waterson, 2013, 2014, submitted). We note however, that there may also be drawbacks with regard to the use of graphical representations. Hollnagel (2004, 2004, pp. 123-124) for example, that accident analysis models such as Accimap are limited to the extent to which they can map multi-causal relationships since they rapidly become overly-complicated when too many casual factors are included (one possible reason, for example, why the average number of contributory causes in our sample is around 35-40 - section 4.2.4).

In some respects questions centred on the reliability and validity of Accimaps may be missing the point. Accimaps are primarily used for the purpose of accident 
analysis (e.g., understanding factors which caused the accident, suggesting countermeasures) and not investigation (e.g., finding a root cause or set of root causes). An analogy might be drawn with some observations made by Karl Weick on the trade-offs involved in developing theory within the social sciences (Weick, 1979) and models and methods for accident analysis. Weick (drawing on earlier work by Thorngate, 1976) uses the metaphor of a clock face to argue that it is impossible for a theory of social behaviour to be simultaneously general, accurate and simple - two of these three characteristics may be possible, but not all three. Thus the more general and simple a theory, for example, the less accurate it will be in predicting specifics. Attempts to secure any two of the 'virtues' of a theory will mean that the third will be sacrificed. 'Two o'clock theories' for example, are general and accurate, but they will not be simple. This clock face analogy might well be usefully applied to tools, models and methods for accident analysis. Accimaps might be said to fit the category of a 'two o'clock method (general and simple), but not necessarily accurate.

\subsubsection{Accimaps and SAA as 'bricolage'}

A final aspect of the 'remixing' process which has taken place in the last decade or so is the construction of new forms of Accimap, alongside combining components (e.g., error taxonomies - study 15, Swiss Cheese, study 19 - HFACS) from other methods and models in order to embellish or improve the outputs from Accimap analysis. The process of constructing these 'hybrid' versions of the original Accimap might be viewed as similar to what the anthropologist Claude Levi-Strauss (1962) called 'bricolage', that is 'the construction [e.g., an artefact, narrative, tool] or creation from a diverse range of available things' (Concise Oxford English Dictionary, 12th Edition, 2011). The process of bricolage is very much in keeping with the pragmatic approach taken by many of the 26 studies, and indeed might well have been Rasmussen’s original intention. Rasmussen and Svedung (2000) present a variety of Accimaps in their report, many of them with different components and with little guidance covering how to construct these. From this point of view articulating and exploring accidents, as well as demonstrating the value and merit of a systemic approach (section 5.1.3 above), may be more important than applying or being bound by strict criteria such as reliability and validity (section 5.1.2). 


\section{Summary and new directions}

Our review of the studies which have followed on from Jens Rasmussen's in the late 1990 's is testament to the influence his work has had on other researchers. Accimaps continue to evolve and Rasmussen's work continues to be 'remixed'. Rasmussen was a pioneer in the field of systemic accident analysis and can be considered as one of the most important founders of the approach. It is a fitting tribute to his work that the tradition of seeing to explain human error beyond individual boundaries has spawned so many followers in the last few decades. Moreover, his legacy has generated both theoretical and practice-oriented debates which are very much grounded within a tradition of research which Lintern (2012) described as work-focused analysis and design. Much of this contrasts with more recent attempts to develop what Dekker (2011) characterises as 'Systems version 2', where the emphasis is perhaps more on conceptual and theoretical description, rather than data-driven analysis and evaluation.

A number of possible future directions for Accimaps are possible, many of which are already underway. Firstly, there is much scope for the further development of 'hybrid' accident models based on the basic Accimap format. Rather than develop new models, there is plenty of scope to 'mix and match' and 'remix' many of the model which already exist (Hovden et al., 2010; Le Coze, 2013). The combination of the HFACS method and Accimaps for example, has already been undertaken by some studies (e.g., study 19), but this could be expanded, or at least experimented with (i.e., in keeping with the spirit of 'bricolage described earlier). Accimaps might benefit from the support of the types of error taxonomic available in HFACS. Likewise, there is scope to develop additional categories of error to suit specific domains (e.g., rail transport) where the HFACS taxonomy may need to be tailored to specific needs and requirements and expanded. Secondly, the guidelines put forward by Branford et al., (2009) could be taken a step further. These might encompass recommendations covering the evaluation and validation of Accimap outputs (e.g., in the manner of some studies which have included these details in their procedure - studies 9, 16 and 22). This sort of future work might help to improve reliability and validity and many, well-respected examples are discernible within the literature on qualitative data analysis (e.g., Corbin and Strauss, 2008), as well as accident analysis (e.g., Snook, 2000). Finally, understanding causality across 
system levels represents a critical challenge for understanding risks to safety (Hettinger et al., 2015).

\section{Acknowledgements}

Earlier versions of this paper were presented at the IEHF 2011, the IET Systems Safety 2010 (Waterson and Jenkins, 2010, 2011) and 2014 ODAM Rasmussen Legacy symposium conferences (Waterson et al., 2014). We are grateful for the constructive suggestions made by a number of people at these conferences.

Word Count $=6,214$ (excluding figures and tables) 


\section{References}

Antonsen, S. (2009), Safety Culture: Theory, Method and Improvement. Farnham: Ashgate.

Baber, C. and Stanton, N.A. (2002) Task analysis for error identification: theory, method and validation. Theoretical Issues in Ergonomics Science, 3, 212-227.

Branford, K. (2007), An investigation into the validity and reliability of the AcciMap approach. Unpublished doctoral dissertation, Australian National University, Canberra, Australia.

Branford, K., Naikar , N. and Hopkins, A. (2009), Guidelines for AcciMap analysis. In A. Hopkins (Ed.), Learning from High Reliability Organisations. Sydney: CCH.

Braun, V. and Clarke, V. (2006) Using thematic analysis in psychology. Qualitative Research in Psychology, 3, 2, 77-101.

Cassano-Piche, A.L., Vicente, K.J. and Jamieson, G.A. (2006). A sociotechnical systems analysis of the BSE epidemic in the UK. Proceedings of the Human Factors and Ergonomics Society Annual Meeting, 50, 386-390.

Cook, R.I. (2014), Rasmussen, engineering, and the influence of indicator diagrams. Presentation at the 'Legacy of Jens Rasmussen' Symposium at ODAM 2014 Conference.

Corbin, J. and Strauss, A. (2008), Basics of Qualitative Research ( ${ }^{\text {rd }}$ Edition). Thousand Oaks: Sage.

de Almeida, I.M. and Johnson, C.W. (2008), Extending the Borders of Accident Investigation: Applying Novel Analysis Techniques to the Loss of the Brazilian Space Programme's Launch Vehicle VLS-1 V03. http://www.dcs.gla.ac.uk/ johnson/papers/Ildeberto_and_Chris.PDF (Accessed June 26th, 2015) 
Dekker, S.W.A. (2011). Systems thinking 1.0 and systems thinking 2.0: Complexity science and a new conception of "cause." Aviation in Focus: An International Aeronautical Journal, 2, 2, 21-39.

Dekker, S.W.A. (2014), The Field Guide to Understanding 'Human Error' $\left(3^{\text {rd }}\right.$ Edition). Farnham: Ashgate.

Dekker, S.W.A, Cilliers, P. and Hofmehr, J-H. (2011), The complexity of failure: implications of complexity theory for safety investigations. Safety Science, 49, 939945.

Edwards, E. (1988), Introductory overview. In E. Wiener and D. Nagel (Eds.), Human Factors in Aviation. San Diego: Academic Press.

Glaser, B. and Strauss, A. (1967), The Discovery of Grounded Theory. Chicago: Aldine.

Goldin, I. and Mariathasan, M. (2014), The Butterfly Defect: How Globalisation Creates Systemic Risks, And What to Do About it. Princeton: Princeton University Press.

Green, A.E. (1988), Human factors in industrial risk assessment - some early work. In L.P. Goodstein, H.B. Andersen and S.E. Olson (Eds.) Tasks, Errors and Mental Models. London: Taylor and Francis.

Hale, A.R., and Hovden J. (1998), Management and culture: the third age of safety: a review of approaches to organisational aspects of safety, health and environment. In A.M. Feyer and A. Williamson (Eds)., Occupational Injury: Risk, Prevention and Intervention. London: Taylor and Francis

Hettinger, L.J., Robertson, M.M., Waterson, P.E., Noy, Y.I., Dainoff, M.J., Leveson, N.G., Carayon, P., Courtney, T.J. (2015), Sociotechnical approaches to workplace safety: research needs and opportunities. Ergonomics, 58, 650-8. 
Holden, R.J. (2009), People or systems: to blame is human. The fix is to engineer. Professional Safety, 12, 34-41.

Hollnagel, E. (2004), Barriers and Accident Prevention. Farnham: Ashgate

Hollnagel, E. (2012), FRAM: The Functional Resonance Analysis Method: Modelling Complex Socio-Technical Systems. Farnham: Ashgate.

Hopkins, A. (2003), Fault Trees, ICAM and AcciMaps: A Methodological Analysis. Unpublished report, Canberra: Australian National University.

House, R., Rousseau, D. M., and Thomas-Hunt, M. (1995), The meso paradigm: a framework for the integration of micro and macro organizational behavior. $\underline{\text { Research }}$ in Organizational Behaviour, 17, 71-114.

Hovden, J., Albrechtsen, E. and Herrera. I.A. (2010), Is there a need for new theories, models and approaches to occupational accident prevention? Safety Science, 48, 8, 950- 956.

Jun, G.T., Kee, R., Waterson, P.E. and Haslam, R.H. (2015), Overturning the bad apple theory: a systems analysis of the South Korea Sewol ferry disaster. Submitted to Applied Ergonomics (special issue on 'Reflecting on the legacy of Jens Rasmussen').

Kanis, H. (2014), Reliability and validity of findings in ergonomics research. Theoretical Issues in Ergonomics Science, 15, 1, 1-46.

Karsh, B-T., Waterson, P.E. and Holden, R. (2014), Crossing levels in systems ergonomics: a framework to support 'mesoergonomic' inquiry. Applied Ergonomics, 45, 45-54.

Katsakiori, P., Sakellaropoulos, G. and Manatakis, E. (2009), Towards an evaluation of accident methods in terms of their alignment with accident causation models, Safety Science, 47, 1007-1015. 
Kontogiannis, T., Leopoulos, V. and Marmaras, N. (2000), A comparison of accident analysis techniques for safety-critical man-machine systems. International Journal of Industrial Ergonomics, 25, 327-347.

Ladkin, P.B. (2001), Causal system analysis, Volume RVS-Bk-05-01. RVS Group, University of Bielefeld, 2001. Available at www.rvs.unibielefeld.de (last accessed $14^{\text {th }}$ December 2010).

Ladkin, P.B. and Loer, K. (1998), Why-Because Analysis: formal reasoning about incidents. Technical Report RVS-Bk-98-01, Faculty of Technology, Bielefeld University. http://www.rvs.uni-bielefeld.de

Le Coze, J. (2013), New models for new times: an anti-dualist move. Safety Science, 59, 200-218.

Le Coze, J-C. (submitted), Reflecting on Jens Rasmussen's Legacy (2) Behind and Beyond, a 'Constructivist Turn'. Submitted to Applied Ergonomics (special issue on 'Reflecting on the legacy of Jens Rasmussen’).

Leplat, J. and Rasmussen, J. (1984), Analysis of human errors in industrial incidents and accidents for improvement of work safety. Accident Analysis and Prevention, 16, 77-88.

Lévi-Strauss, C. (1966), The Savage Mind. Chicago, IL: University of Chicago Press.

Lintern, G. (2012), Work-focused analysis and design. Cognition, Technology and Work.

Leveson, N. (2004), A new accident model. Safety Science, 42, 237-270. 
Leveson, N. (submitted), Rasmussen’s legacy: a paradigm change in engineering for safety. Submitted to Applied Ergonomics (special issue on 'Reflecting on the legacy of Jens Rasmussen').

Leveson, N., Dulac, N., Marais, K. and Carroll, J. (2009), Moving beyond normal accidents and high reliability organizations: A systems approach to safety in complex systems. Organisation Studies, 30, 02-03, 227-249.

Murray, S., Jun, G.T. and Waterson, P.E. (submitted), Human and organisational factors involved in commercial shipping accidents: a systems-based analysis focusing on collisions. Accident Analysis and Prevention.

Nayak, R. and Waterson, P.E. (in preparation), 'When Food Kills': A sociotechnical systems analysis of the UK Pennington 1996 and 2005 E.coli O157 outbreak reports. Safety Science.

Neisser, U. (1976), Cognition and Reality. San Francisco: W.H. Freeman.

Pennington, T.H. (2003), When Food Kills: BSE, E.coli and Disaster Science. Oxford: Oxford University Press

Perrow, C. (1984), Normal Accidents. New York: Basic Books.

Rasmussen, J. (1968), On the communication between operators and instrumentation in automatic process plants. Report: Riso-M-686. Reprinted in E. Edwards. And F.P. Lees (Eds., 1974), The Human Operator in Process Control. London: Taylor and Francis

Rasmussen, J. (1974), The human data processor as a system component: bits and pieces of a model. Report No. Riso-M-1722. Roskilde, Denmark: Danish Atomic Energy Commission.

Rasmussen, J. (1980), The human as a systems component. In H.T. Smith and T.R.G. Green (Eds.), Human Interaction with Computers. London: Academic Press. 
Rasmussen, J. (1982), Human errors. A taxonomy for describing human malfunction in industrial applications. Journal of Occupational Accidents, 4, 311333.

Rasmussen, J. (1986). Information Processing and Human-Machine Interaction: An Approach to Cognitive Engineering. New York: North Holland.

Rasmussen, J. (1990), Human error and the problem of causality in analysis of accidents. Philosophical Transactions of the Royal Society, London, Part B, 327, 449-62.

Rasmussen, J. (1997), Risk management in a dynamic society: a modelling problem. Safety Science, 27, 183-213.

Rasmussen, J. (1999), Preface. In K.J. Vicente (Ed.), Cognitive Work Analysis: Productive, and Healthy Computer-Based Work. Boca Raton: CRC Press.. Boca Raton: CRC Press.

Rasmussen, J. and Svedung, I. (2000), Proactive Risk Management in a Dynamic Society. Karlstad: Swedish Rescue Services Agency.

Rasmussen, J. Pejtersen, A.M. and Goodstein, L.P. (1994), Cognitive Systems Engineering. New York: Wiley.

Reason J.T. (1990), Human Error. Cambridge: Cambridge University Press.

Reason J.T. (1999) Are we casting the net too widely in our search for the factors contributing to errors and accidents? In J. Misumi, B. Wilpert and R. Miller (Eds.) Nuclear Safety: An Ergonomics Perspective. Boca Raton: CRC Press.

Ryan, B. (2015), Incident reporting and analysis. In J.R. Wilson and S. Sharples (Eds.), Evlaution of Human Work ( $4^{\text {th }}$ Edition). Boca Raton: CRC Press. 
Sanderson, P.M. and Harwood, K. (1988), The Skills, Rules and Knowledge classification: a discussion of its emergence and nature. On L.P. Goodstein, H.B. Andersen and S.E. Olson (Eds.) Tasks, Errors and Mental Models. London: Taylor and Francis.

Shorrock, S., Young, M., Faulkner, J. and Braithwaite, G. (2004) Who moved my (Swiss) cheese? The (R)evolution of human factors in transport safety investigation.

ISASI Proceedings, session IX, 141-144. Available at: http://www.asasi.org/papers/2004/Young\%20et\%20al_Human\%20Factors_ISASI04 .pdf. (Last accessed April $5^{\text {th }}$ 2015)

Sklet, S. (2004), Comparison of some selected methods for accident investigation, Journal of Hazardous Materials, 111, 29-37.

Snook, S.A. (2000), Friendly Fire: The Accidental Shooting Down of U.S. Black Hawks Over Northern Iraq. Princeton: Princeton University Press.

Svedung, I., and Rasmussen, J. (2002). Graphic representation of accident scenarios: mapping system structure and the causation of accidents. Safety Science, 40, 397-417.

Thorngate, W. (1976), "In general” vs. "it depends“: Some comments on the Gergen-Schlenker debate. Personality and Social Psychology Bulletin, 2, 404-410

Turner, B.A. (1978), Man-Made Disasters. London: Wykeham Publications.

Underwood, P. and Waterson, P.E. (2013), Systemic accident analysis: examining the gap between research and practice. Accident Analysis and Prevention, 55, 154164.

Underwood, P., Waterson, P.E. and Braithwaite, G. (submitted) 'Accident investigation in the wild' - a small-scale, field-based evaluation of the STAMP method for accident analysis. Safety Science 
Vaughan, D. (1992). Theory elaboration: the heuristic of case analysis. In C. Ragin, and H. Becker (Eds.), What is a Case? Exploring the Foundations of Social Enquiry. New York: Cambridge University.

Vicente, K.J. (1999). Cognitive Work Analysis: Toward Safe, Productive, and Healthy Computer-based Work. Mahwah, NJ: Lawrence Erlbaum Associates.

Vicente, K.J. (2001), Cognitive engineering research at Risø from 1962-1979. In E. Salas (Ed.), Advances in Human Performance and Cognitive Engineering Research - Volume 1. Emerald Group Publishing Limited.

Wagenaar, W.A. and van der Schrier, J. (1997), Accident analysis - the goal, and how to get there, Safety Science, 26, 25-33.

Waterson, P.E. and Jenkins, D.T. (2010), Methodological considerations in using Accimaps and the Risk Management Framework to analyse large-scale systemic failures. IET Systems Safety Conference 2010 (IET CD-ROM Proceedings).

Waterson, P.E. and Jenkins, D.T. (2011), Lessons learnt from using Accimaps and the Risk Management Framework to analyse large-scale systemic failures. In M. Anderson (Ed.) Contemporary Ergonomics 2011, pp. 6-13, London: Taylor and Francis.

Waterson, P.E., Clegg, C.W. and Robinson, M. (2014), Trade-offs between reliability, validity and utility in the development of human factors methods. In O. Broberg, N. Fallentin, P. Hasle, P.L. Jensen, A. Kabel, M.E. Larsen, T. Weller (Editors), Human Factors in Organizational Design and Management XI. Santa Monica: IEA Press

Waterson. P.E., Robertson, M.M., Cooke, N.J. Militello, L, Roth, E. and Stanton, N.A. (2015), Defining the methodological challenges and opportunities for an effective science of sociotechnical systems and safety. Ergonomics, 58, 4, 565-599. 
Weick, K. (1979), The Social Psychology of Organizing. Reading, Mass.: AddisonWesley.

Weick, K. (1995), Sensemaking in Organisations. Reading, Mass.: Addison-Wesley.

Zohar, D. (1980), Safety climate in industrial organizations: theoretical and applied implications. Journal of Applied Psychology, 65, 96-102. 


\section{Appendix 1: Research using Accimaps (2000-2015)}

1. Hopkins, A. (2000), Lessons From Longford: The Esso Gas Plant Explosion. Sydney: CCH.

2. Woo, D. M., and Vicente, K. J. (2003), Sociotechnical systems, risk management, and public health: Comparing the North Battleford and Walkerton outbreaks. Reliability Engineering and System Safety, 80, 253-269.

3. Ladkin, P.B. (2005), Why-Because analysis of the Glenbrook, NSW rail accident and comparison with Hopkin's Accimap. Research Report RVS-RR05-05, Faculty of Technology, University of Bielefeld.

4. Vicente, K.J. and Christoffersen, K. (2006), The Walkerton E. coli outbreak: a test of Rasmussen's framework for risk management in a dynamic society. Theoretical Issues in Ergonomics Science, 7, 2, 93-112.

5. Johnson, C.W. and de Almeida, I.M., (2008) An investigation into the loss of the Brazilian space programme’s launch vehicle VLS-1 V03, Safety Science, 46, 1, 38-53.

6. Cassano-Piche, A.L., Vicente, K.J. and Jamieson, G.A. (2009). A test of Rasmussen's risk management framework in the food safety domain: BSE in the UK. Theoretical Issues in Ergonomics Science, 10(4), pp. 283-304.

7. Waterson, P.E. (2009), A systems ergonomics analysis of the Maidstone and Tunbridge Wells infection outbreaks. Ergonomics, 52, 10, 1196-1205.

8. Salmon, P., Williamson, A., Lenne, M., Mitsopoulos-Rubens, E. and RudinBrown, C.M. (2010), Systems-based accident analysis in the led outdoor activity domain: application and evaluation of a risk management framework. Ergonomics, 53, 8, 927-939.

9. Salmon, P., Cornelissen, M. and Trotter, M.J. (2012), Systems-based analysis methods: a comparison of Accimap, HFACS and STAMP. Safety Science, 50, 1158-1170.

10. Jenkins, D.P., Salmon, P.M., Stanton, N.A. and Walker, G.H. (2010), A systemic approach to accident analysis: A case study of the Stockwell shooting. Ergonomics, 53, 1-17.

11. Jenkins, D.P., Salmon, P.M., Stanton, N.A., Walker, G.H. and Rafferty, L. (2011), What could they have been thinking? How sociotechnical system design 
influences cognition: a case study of the Stockwell shooting. Ergonomics, 54, 2, 103-119.

12. Le Coze, J-C. (2008), Disasters and organizations: from lessons learnt to theorizing. Safety Science, 46, 132-149.

13. Andersson, J. (2010), Using Accimaps to describe the emergence of critical work situations - a systemic approach to analyse evaluation. In D. de Waard, A. Axelson, M. Berglund, B. Peters and C. Weikert (Eds.), Human Factors: A System View of Human, Technology and Organisation. Maastricht: Shaker Publishing.

14. Branford, K. (2011), Seeing the big picture of mishaps - applying the AcciMap approach to analyze system accidents. Aviation Psychology and Applied Human Factors, 1, 1, 31-37.

15. Deprincat, J., Bil, C. and Clark, G. (2013), Assessing organisational factors in aircraft accidents using a hybrid Reason and AcciMap model. Engineering Failure Analysis, 27, 52-60.

16. Salmon, P.M., Goode, N., Stanton, N.A. and Lenne, M. (2013), The crash at Kerang: investigating systemic and psychological factors leading to unintentional non-compliance at rail level crossings. Accident Analysis and Prevention, 50, 1278-1288.

17. Underwood, P. and Waterson, P.E. (2014), Systems thinking, the Swiss Cheese model and accident analysis: a comparative systems analysis of the Grayrigg train derailment using the ATSB, Accimap and STAMP models. Accident Analysis and Prevention, 68, 75-94.

18. Scott-Parker, B., Goode, N. and Salmon, P.M. (2015), The driver, the road, the rules......and the rest? A systems-based approach to young driver road safety. Accident Analysis and Prevention, 74, 297-305.

19. Lei, G., Zhang, S. Tang, P. and Lu, Y. (2014), An integrated graphictaxonomic-associative approach to analyze human factors in aviation. $\underline{\text { Chinese }}$ Journal of Aviation, 27, 2, 226-240.

20. Trotter, M.J., Salmon, P.M. and Lenne, M. (2014), Impromaps: Applying Rasmussen’s Risk Management Framework to improvisation incidents. Safety Science, 64, 60-70.

21. Salmon, P.M., Goode, N., Archer, F., Spencer, C., McArdle, D. and McClure, R.J. (2014), A systems approach to examining disaster response: Using Accimap 
to describe the factors influencing bushfire response. Safety Science, 70, 114122.

22. Harvey, C. and Stanton, N.A. (2014). Safety in System-of-Systems: Ten key challenges. Safety Science, 70, 358-366.

23. Tabibzadeh, M. and Meshkati, N. (2015), Applying the AcciMap methodology to investigate a major accident in offshore drilling: a systematic risk management framework for oil and gas industry. Society of Petroleum Engineers, SPE Western Regional Meeting, 27-30 April, Garden Grove, California, USA.

24. Fan, Y., Zhu, J., Pei, J., Li, Z. and Wu, Y. (2015), Analysis for Yangmingtan bridge collapse. Engineering Failure Analysis (in press). http://dx.doi.org/10.1016/j.engfailanal.2015.05.003

25. Newman, S. and Goode, N. (2015), Do not blame the driver: a systems analysis of the causes of road freight crashes. Accident Analysis and Prevention, 76, 141151.

26. Stefanova, T., Burkhardt, J-M., Filtness, A., Wullems, C., Rakotonirainy, A. and Delhomme, P. (2015), Systems-based approach to investigate unsafe pedestrian behaviour at level crossings. Accident Analysis and Prevention, 81, 167-186. 
Figure 1: The development of methods for sociotechnical systems and safety (adapted from Waterson et al., 2015)

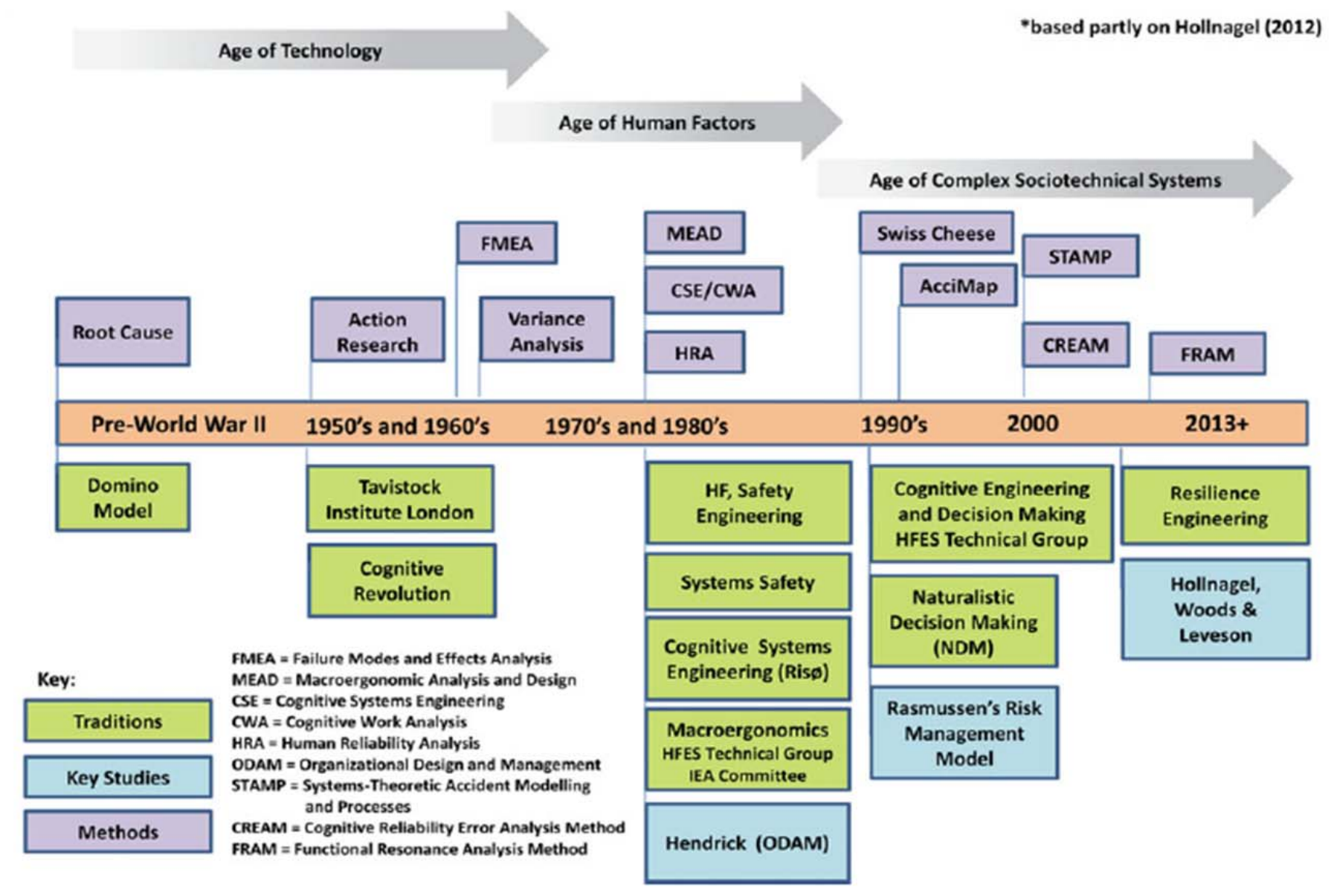


Figure 2: Dynamic model of safety and system performance (Rasmussen, 1997)

J. Kasm

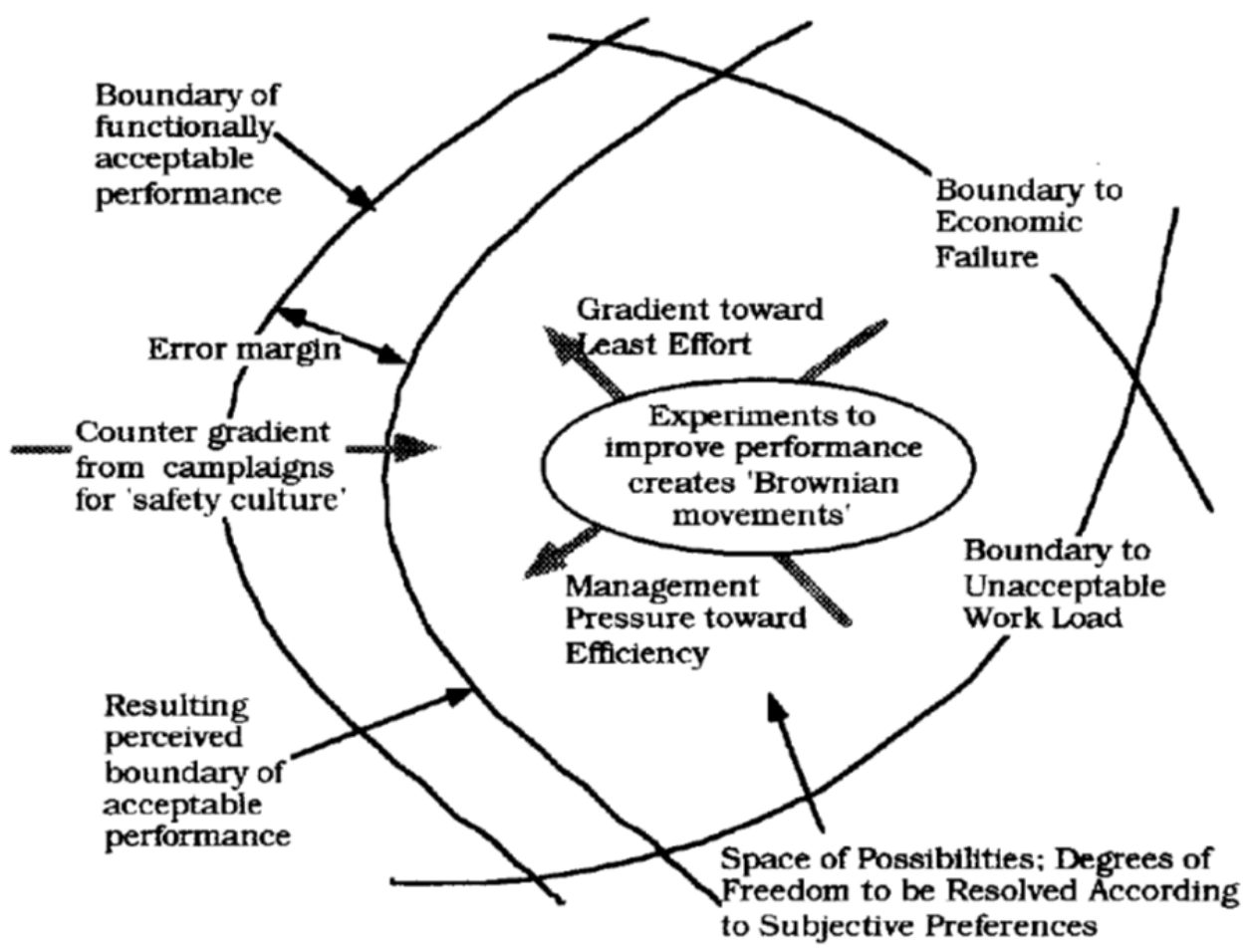


Figure 3: (a) Citations of Rasmussen (1997) over the period 2000- June 2015; (b) Citations of Rasmussen and Svedung (2000) over the period 2000- June 2015

(a)

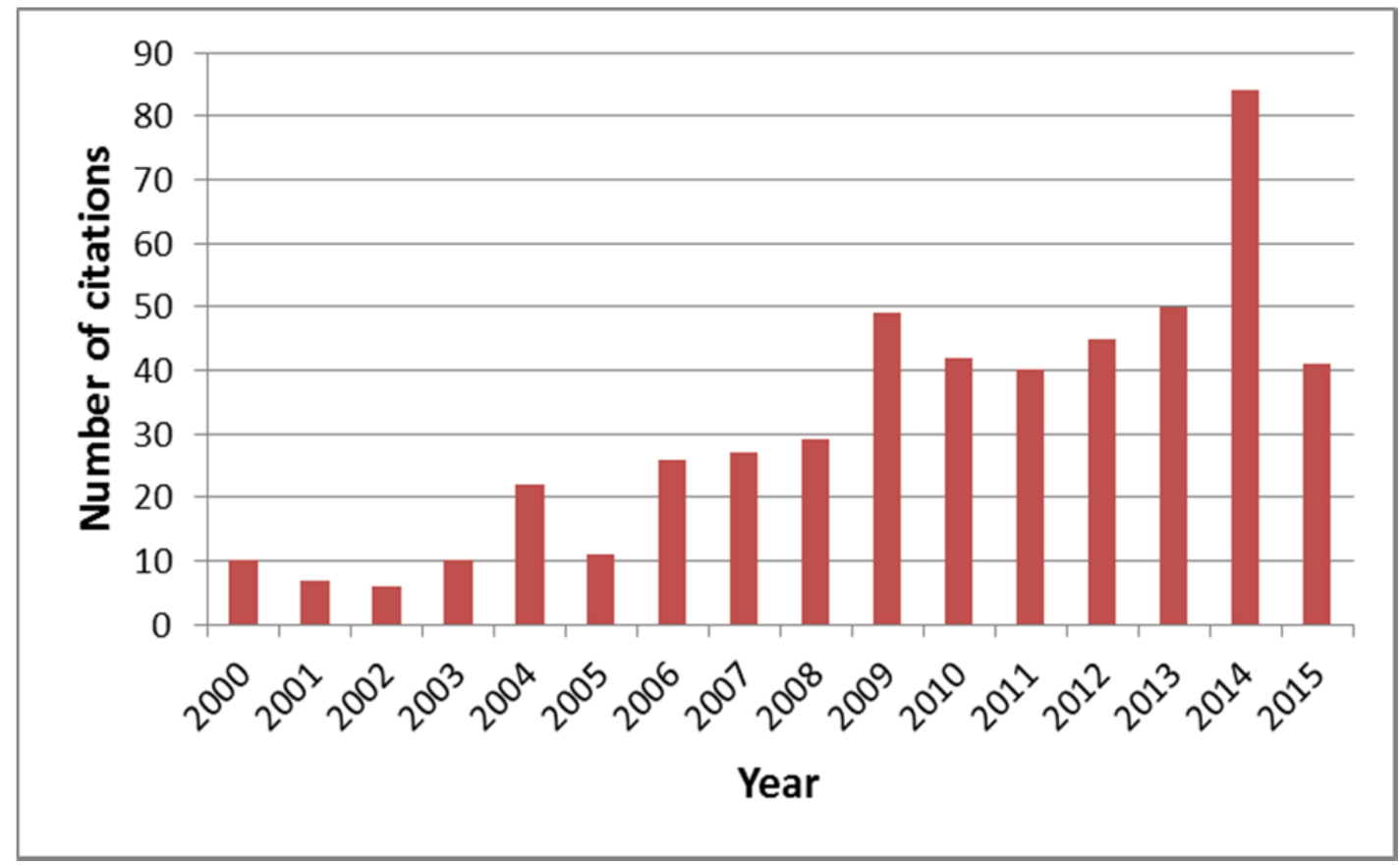

(b)

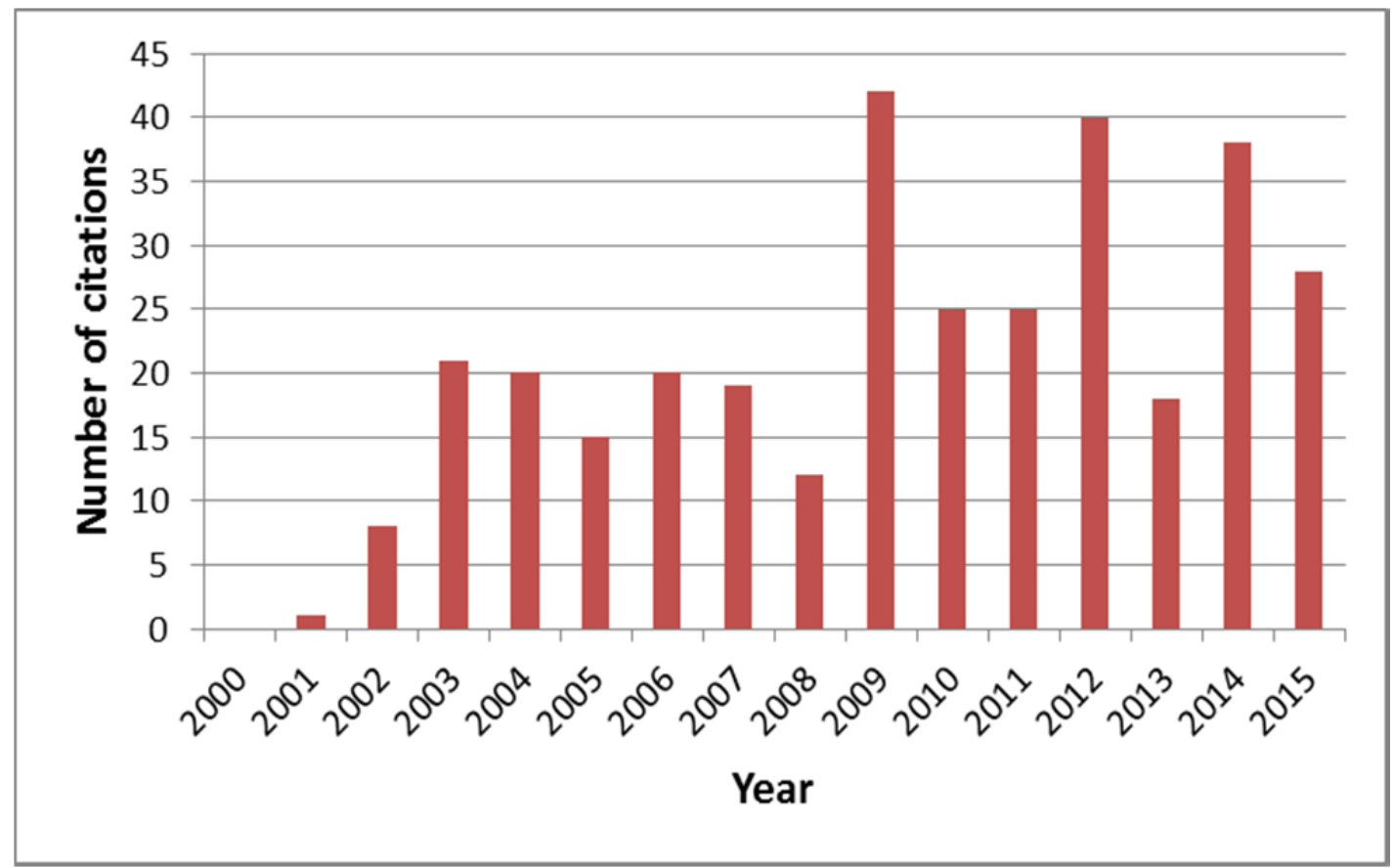


Figure 4: The risk management framework (Rasmussen, 1997)

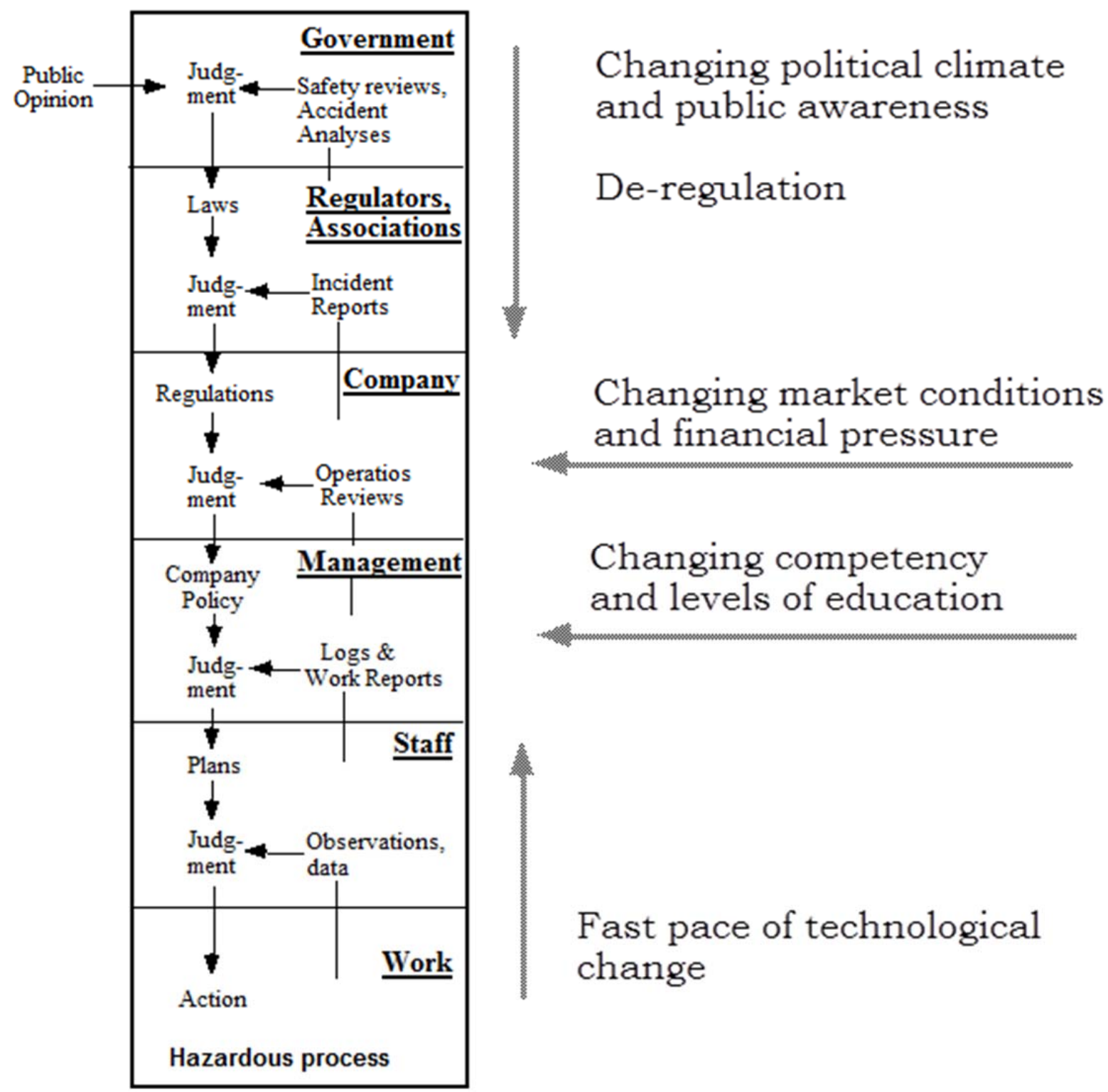


Figure 5: Accimap diagram format (adapted from Rasmussen and Svedung,

2000, p. 21)

SYSTEM LEVEL

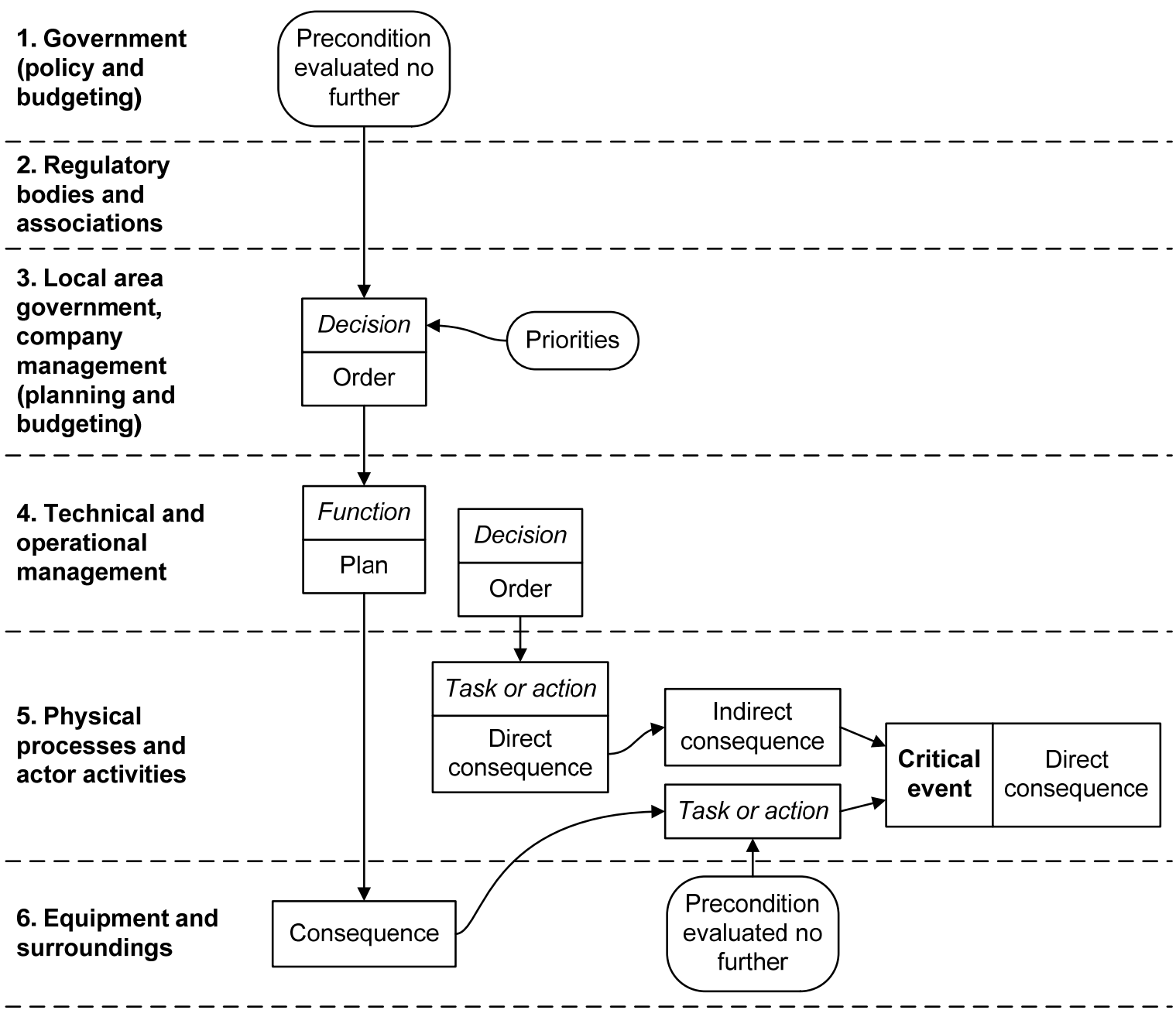


Figure 6: The operator’s ‘ladder of abstraction’ Rasmussen (1974)

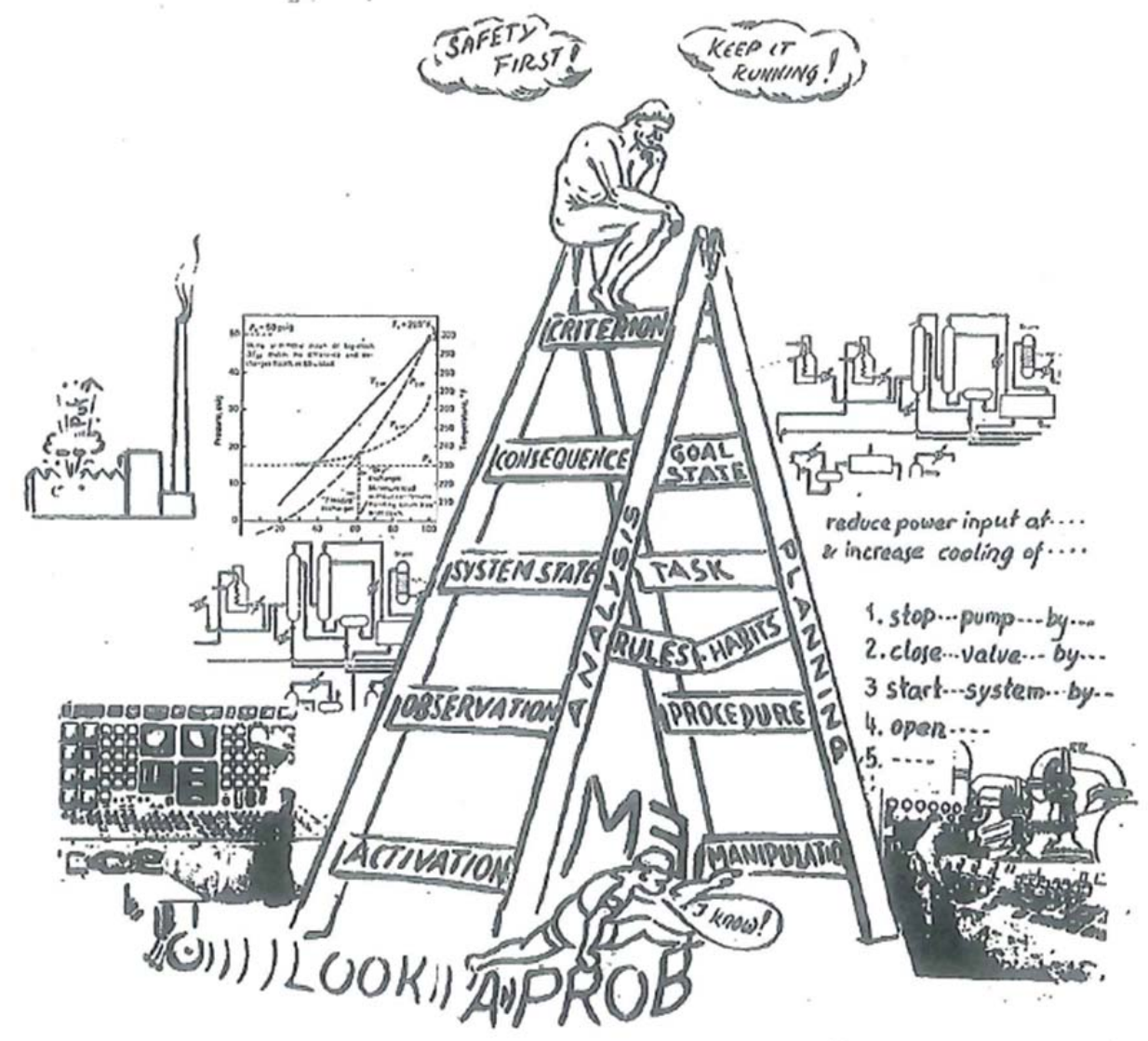


Figure 7: Complex interaction in a man-machine system (Rasmussen, 1982)

INELUENCE EROM SYSTEH

AND ENULRONMENT

HURAN OPRRETOR YUNCTIONS

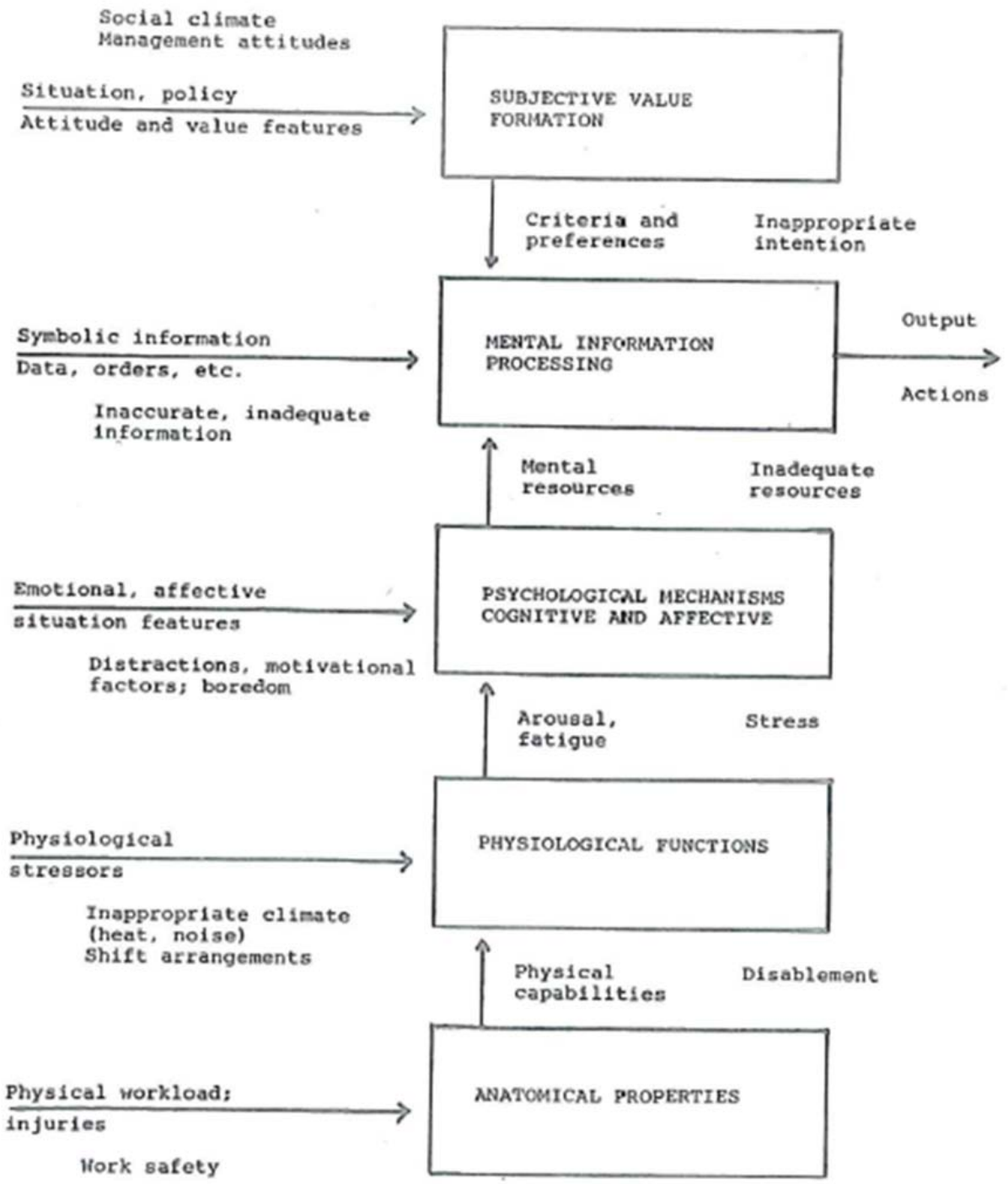


Figure 8: Diagram of control system (Rasmussen, 1968)

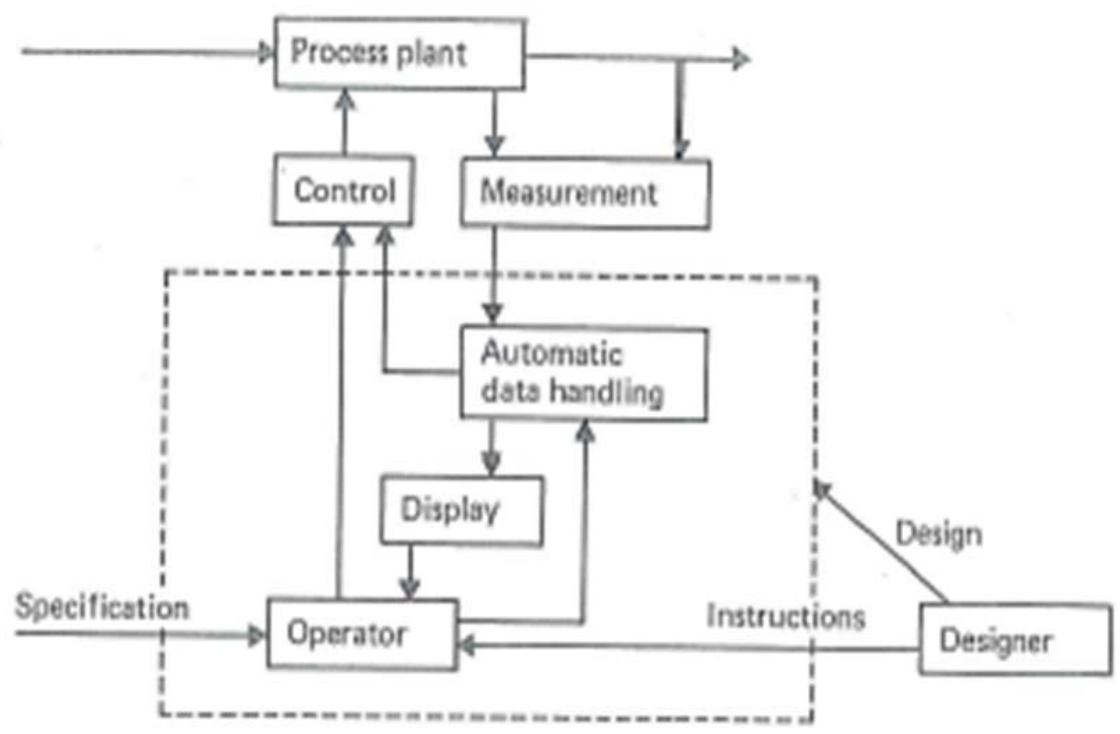

Data handling

Takks for Control Syatem; Operator ad/or Instramentation

Normal operation: Optimixing of operation

Sequence control (e.y. start-atop)

Recosding of operational information

Abnormal operation: Detection of abnomal gtatea

Identification, ovaluation of consequenees

Decision, choice of sppropriate counter-measurva

Action, eontrol of cerrecting sequence 
Figure 9: Model of the human operator in a control system (Rasmussen, 1980)

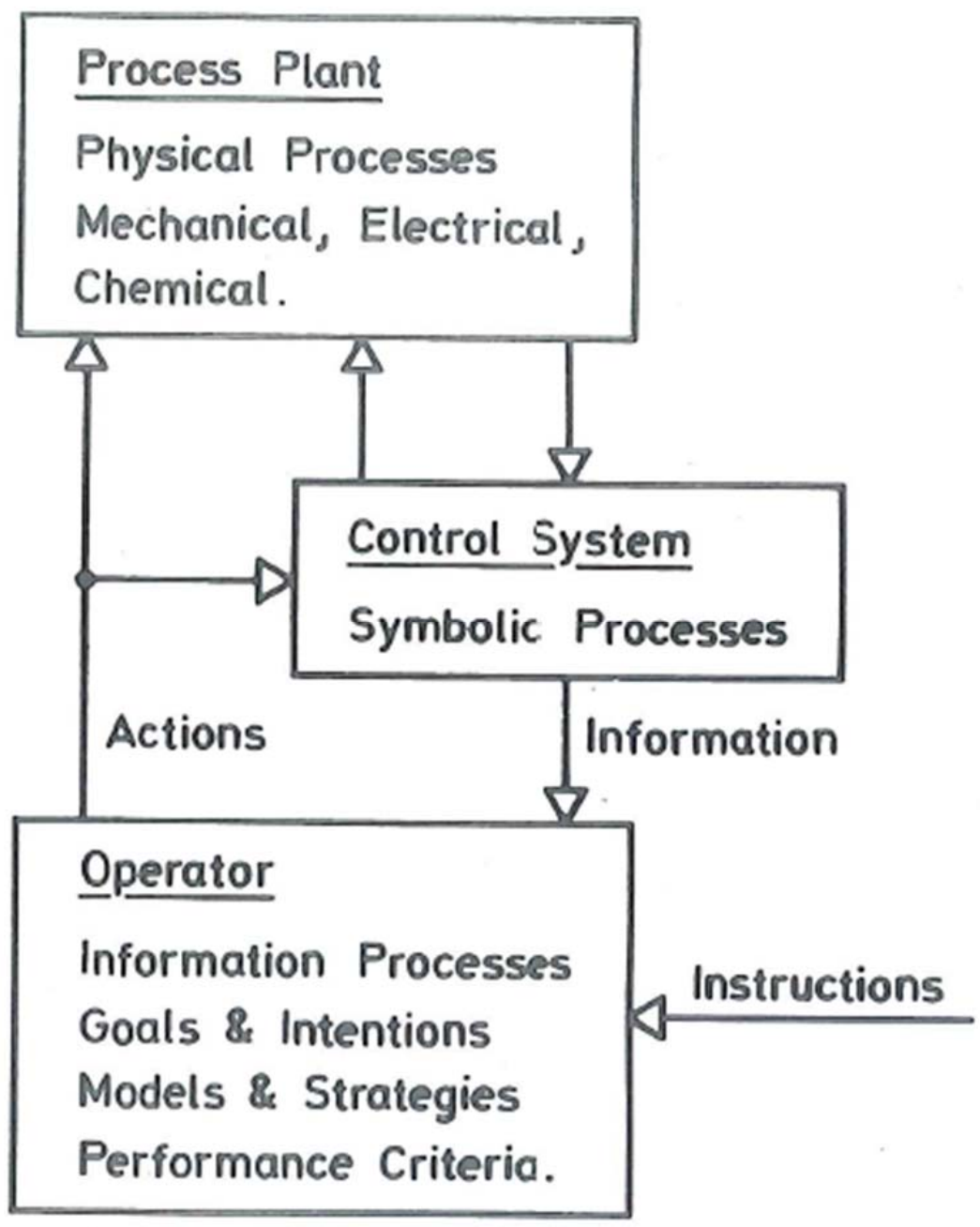


Table 1: Database search results

\begin{tabular}{|c|c|c|}
\hline Database & Number of hits & $\begin{array}{c}\text { Articles describing use of } \\
\text { Accimaps }\end{array}$ \\
\hline Web of Science & 15 & 13 \\
\hline Google Scholar & 251 & 21 \\
\hline $\begin{array}{c}\text { Ergonomics } \\
\text { Abstracts }\end{array}$ & 11 & 11 \\
\hline PsycINFO & 9 & 9 \\
\hline
\end{tabular}




\section{Table 2: Study sample}

\begin{tabular}{|c|c|c|}
\hline & Study Authors & Study Title \\
\hline 1 & Hopkins (2000) & Lessons From Longford: The Esso Gas Plant Explosion \\
\hline 2 & Woo and Vicente (2003) & Sociotechnical systems, risk management, and public health: comparing the North Battleford and Walkerton outbreaks \\
\hline 3 & Ladkin (2005) & Why-Because analysis of the Glenbrook, NSW rail accident and comparison with Hopkin's AcciMap \\
\hline 4 & Vicente and Christophsen (2006) & The Walkerton E. coli outbreak: a test of Rasmussen's framework for risk management in a dynamic society \\
\hline 5 & Johnson and de Almeida (2008) & An investigation into the loss of the Brazilian space programme's launch vehicle VLS-1 V03 \\
\hline 6 & Cassano-Piche et al. (2009) & A test of Rasmussen's risk management framework in the food safety domain: BSE in the UK \\
\hline 7 & Waterson (2009) & A systems ergonomics analysis of the Maidstone and Tunbridge Wells infection outbreaks \\
\hline 8 & Salmon et al. (2010) & Systems-based accident analysis in the led outdoor activity domain: application and evaluation of a risk management framework \\
\hline 9 & Salmon et al. (2012) & Systems-based analysis methods: a comparison of Accimap, HFACS and STAMP. \\
\hline 10 & Jenkins et al. (2010) & A systemic approach to accident analysis: A case study of the Stockwell shooting. \\
\hline 11 & Jenkins et al. (2011) & What could they have been thinking? How sociotechnical system design influences cognition: a case study of the Stockwell shooting \\
\hline 12 & Le Coze (2010) & Accident in a French dynamite factory: An example of an organisational investigation \\
\hline 13 & Andersson (2010) & Using Accimaps to describe the emergence of critical work situations - a systemic approach to analyse evaluation \\
\hline 14 & Branford (2011) & Seeing the big picture of mishaps - applying the AcciMap approach to analyze system accidents \\
\hline 15 & Debrincat et al. (2013) & Assessing organisational factors in aircraft accidents using a hybrid Reason and AcciMap model \\
\hline 16 & Salmon et al. (2013) & The crash at Kerang: Investigating systemic and psychological factors leading to unintentional non-compliance at rail level crossings \\
\hline 17 & Underwood and Waterson (2014) & Systems thinking, the Swiss Cheese model and accident analysis: a comparative systems analysis of the Grayrigg train derailment using the ATS \\
\hline
\end{tabular}




\section{Table 2: Study sample}

\begin{tabular}{|c|c|c|}
\hline & Study Authors & Study Title \\
\hline & & Accimap and STAMP models \\
\hline 18 & Scott-Parker et al. (2014) & The driver, the road, the rules ... and the rest? A systems-based approach to young driver road safety \\
\hline 19 & Lei et al. (2014) & An integrated graphic-taxonomic-associative approach to analyze human factors in aviation accidents \\
\hline 20 & Trotter et al. (2014) & Impromaps: Applying Rasmussen's Risk Management Framework to improvisation incidents \\
\hline 21 & Salmon et al. (2014) & A systems approach to examining disaster response: Using Accimap to describe the factors influencing bushfire response \\
\hline 22 & Harvey and Stanton (2014) & Safety in System-of-Systems: Ten key challenges \\
\hline 23 & Tabinzadeh and Meshkati (2015) & $\begin{array}{l}\text { Applying the AcciMap methodology to investigate a major accident in offshore drilling: a systematic risk management framework for oil and gas } \\
\text { industry }\end{array}$ \\
\hline 24 & Fan et al. (2015) & Analysis for Yangmingtan bridge collapse. \\
\hline 25 & Newman and Goode (2015) & Do not blame the driver: a systems analysis of the causes of road freight crashes \\
\hline 26 & Stefanova et al. (2015) & Systems-based approach to investigate unsafe pedestrian behaviour at level crossings \\
\hline
\end{tabular}


Table 3: Applying the framework to the 26 studies

\begin{tabular}{|c|c|c|c|c|c|c|c|c|c|}
\hline & 1 & 2 & 3 & 4 & 5 & 6 & 7 & 8 & 9 \\
\hline & Hopkins (2000) & $\begin{array}{l}\text { Woo and Vicente } \\
\text { (2003) }\end{array}$ & Ladkin (2005) & $\begin{array}{c}\text { Vicente and } \\
\text { Christopherson } \\
(2006)\end{array}$ & $\begin{array}{l}\text { Johnson and de } \\
\text { Almeida (2008) }\end{array}$ & $\begin{array}{l}\text { Cassano-Piche et } \\
\text { al. (2009) }\end{array}$ & Waterson (2009) & $\begin{array}{c}\text { Salmon et al } \\
(2010)\end{array}$ & $\begin{array}{l}\text { Salmon et al. } \\
\text { (2012) }\end{array}$ \\
\hline $\begin{array}{l}\text { Context of } \\
\text { use }\end{array}$ & $\begin{array}{l}\text { Oil and Gas - } \\
\text { Explosion at Esso } \\
\text { Gas Plant in } \\
\text { Longford, } \\
\text { Australia resulting } \\
\text { in } 2 \text { fatalities and } \\
\text { widespread } \\
\text { disruption }\end{array}$ & $\begin{array}{l}\text { Public Heath - } \\
\text { Comparison of two } \\
\text { public health E. coli } \\
\text { outbreaks in Canada } \\
\text { (North Battleford and } \\
\text { Walkerton) }\end{array}$ & $\begin{array}{l}\text { Rail - Glenbrook } \\
\text { train collision } \\
\text { (1999) }\end{array}$ & $\begin{array}{l}\text { Public Health - } \\
\text { Walkerton } \\
\text { E. coli outbreak }\end{array}$ & $\begin{array}{l}\text { Aerospace- } \\
\text { Explosion of } \\
\text { Brazilian Space } \\
\text { Vehicle }\end{array}$ & $\begin{array}{l}\text { Public Health - UK } \\
1996 \text { BSE ('Mad } \\
\text { Cow' Disease) } \\
\text { outbreak }\end{array}$ & $\begin{array}{l}\text { Public Health } \\
\text { (Hospital) - } \\
\text { Outbreaks of } \\
\text { Clostridium } \\
\text { difficile at } \\
\text { Maidstone and } \\
\text { Tunbridge Wells } \\
\text { NHS Trust (2005- } \\
\text { 2007) }\end{array}$ & $\begin{array}{l}\text { Outdoor } \\
\text { Recreation - } \\
\text { Lyme Bay } \\
\text { Canoeing } \\
\text { Incident (1993) } \\
\end{array}$ & $\begin{array}{l}\text { Outdoor } \\
\text { Recreation - } \\
\text { Mangatepopo } \\
\text { Gorge Incident } \\
\text { (2008) }\end{array}$ \\
\hline $\begin{array}{l}\text { Goals and } \\
\text { objectives }\end{array}$ & $\begin{array}{l}\text { Attempt to lay out } \\
\text { 'causal networks' } \\
\text { leading up to the } \\
\text { explosion } \\
\text { (Hopkins, 2000, p. } \\
\text { 120) }\end{array}$ & $\begin{array}{l}\text { Analysis of complex } \\
\text { socio-technical } \\
\text { factors contributing to } \\
\text { outbreaks (emphasis } \\
\text { on public policy and } \\
\text { public health) }\end{array}$ & $\begin{array}{l}\text { Comparison with } \\
\text { Accimap } \\
\text { developed by } \\
\text { Hopkins (2005) }\end{array}$ & $\begin{array}{l}\text { Analysis of } \\
\text { complex socio- } \\
\text { technical factors } \\
\text { contributing to } \\
\text { outbreaks } \\
\text { (emphasis on } \\
\text { public policy and } \\
\text { public health) }\end{array}$ & $\begin{array}{l}\text { Analysis of } \\
\text { complex socio- } \\
\text { technical factors } \\
\text { contributing to the } \\
\text { explosion and how } \\
\text { this developed over } \\
\text { time. Comparison } \\
\text { with STAMP } \\
\text { analysis (Leveson, } \\
\text { 2003) }\end{array}$ & $\begin{array}{l}\text { Analysis of } \\
\text { complex socio- } \\
\text { technical factors } \\
\text { contributing to } \\
\text { outbreaks } \\
\text { (emphasis on role } \\
\text { played by food } \\
\text { production supply } \\
\text { chain) }\end{array}$ & $\begin{array}{l}\text { Analysis of } \\
\text { complex socio- } \\
\text { technical factors } \\
\text { contributing to } \\
\text { outbreaks } \\
\text { (emphasis on } \\
\text { role played by } \\
\text { organisational/ } \\
\text { regulatory factors } \\
\text { which contributed } \\
\text { to the outbreaks } \\
\text { - e.g., Trust } \\
\text { management) }\end{array}$ & $\begin{array}{l}\text { Testing the } \\
\text { usefulness of the } \\
\text { Accimap } \\
\text { approach for } \\
\text { explaining how } \\
\text { and why } \\
\text { accidents occur } \\
\text { in the outdoor } \\
\text { domain (Salmon } \\
\text { et al., 2010, p. } \\
\text { 927) }\end{array}$ & $\begin{array}{l}\text { Case study } \\
\text { based on } \\
\text { Mangatepopo } \\
\text { Gorge Incident } \\
\text { comparison of } \\
\text { three methods - } \\
\text { Accimap, HFACS } \\
\text { and STAMP }\end{array}$ \\
\hline
\end{tabular}


Table 3: Applying the framework to the 26 studies

\begin{tabular}{|c|c|c|c|c|c|c|c|c|c|}
\hline & 1 & 2 & 3 & 4 & 5 & 6 & 7 & 8 & 9 \\
\hline & Hopkins (2000) & $\begin{array}{l}\text { Woo and Vicente } \\
\text { (2003) }\end{array}$ & Ladkin (2005) & $\begin{array}{c}\text { Vicente and } \\
\text { Christopherson } \\
\text { (2006) }\end{array}$ & $\begin{array}{l}\text { Johnson and de } \\
\text { Almeida (2008) }\end{array}$ & $\begin{array}{c}\text { Cassano-Piche et } \\
\text { al. (2009) }\end{array}$ & Waterson (2009) & $\begin{array}{c}\text { Salmon et al } \\
(2010)\end{array}$ & $\begin{array}{l}\text { Salmon et al. } \\
\text { (2012) }\end{array}$ \\
\hline $\begin{array}{l}\text { Theoretical } \\
\text { background }\end{array}$ & $\begin{array}{l}\text { Organisational } \\
\text { Sociology; } \\
\text { Findings partly } \\
\text { interpreted } \\
\text { through High } \\
\text { Reliability } \\
\text { Organisation } \\
\text { (HRO) theory }\end{array}$ & $\begin{array}{l}\text { Rasmussen's model } \\
\text { of boundaries of } \\
\text { acceptable and } \\
\text { unacceptable } \\
\text { performance } \\
\text { (Rasmussen, 1997) }\end{array}$ & $\begin{array}{l}\text { Logic, computer } \\
\text { science approach } \\
\text { towards complex } \\
\text { systems analysis }\end{array}$ & $\begin{array}{l}\text { Rasmussen's } \\
\text { model of } \\
\text { boundaries of } \\
\text { acceptable and } \\
\text { unacceptable } \\
\text { performance } \\
\text { (Rasmussen, } \\
\text { 1997) }\end{array}$ & $\begin{array}{l}\text { Safety-critical } \\
\text { systems and } \\
\text { Rasmussen's } \\
\text { model of risk } \\
\text { management and } \\
\text { socio-technical } \\
\text { failure } \\
\text { (Rasmussen, 1997) }\end{array}$ & $\begin{array}{l}\text { Rasmussen's } \\
\text { model of } \\
\text { boundaries of } \\
\text { acceptable and } \\
\text { unacceptable } \\
\text { performance } \\
\text { (Rasmussen, 1997) }\end{array}$ & $\begin{array}{l}\text { Sociotechnical } \\
\text { systems theory; } \\
\text { Rasmussen's risk } \\
\text { management } \\
\text { framework (1997) } \\
\text { ) }\end{array}$ & $\begin{array}{l}\text { Sociotechnical } \\
\text { systems theory; } \\
\text { k Rasmussen's risk } \\
\text { management } \\
\text { framework (1997) }\end{array}$ & $\begin{array}{l}\text { Sociotechnical } \\
\text { systems theory; } \\
\text { k Rasmussen's risk } \\
\text { management } \\
\text { framework (1997) }\end{array}$ \\
\hline Procedure & $\begin{array}{l}\text { No explicit } \\
\text { mention of } \\
\text { procedure } \\
\text { (Hopkins, 2000, p. } \\
\text { 122) }\end{array}$ & $\begin{array}{l}\text { No explicit mention o } \\
\text { procedure }\end{array}$ & $\begin{array}{l}\text { fNo explicit } \\
\text { mention of } \\
\text { procedure }\end{array}$ & $\begin{array}{l}\text { No explicit } \\
\text { mention of } \\
\text { procedure }\end{array}$ & $\begin{array}{l}\text { No explicit mention } \\
\text { of procedure but } \\
\text { authors discuss } \\
\text { issues related to } \\
\text { reliability and } \\
\text { validity of their } \\
\text { analyses }\end{array}$ & $\begin{array}{l}\text { No explicit mention } \\
\text { of procedure, but } \\
\text { coverage of how } \\
\text { predictions were } \\
\text { linked to aspects of } \\
\text { the Accimap and } \\
\text { Conflict Maps }\end{array}$ & $\begin{array}{l}\text { Two stages: (1) } \\
\text { System } \\
\text { description - } \\
\text { mainly involving } \\
\text { f document } \\
\text { analysis and } \\
\text { coding; (2) } \\
\text { System } \\
\text { modelling based } \\
\text { on Risk } \\
\text { Management } \\
\text { Framework } \\
\text { (Rasmussen, } \\
\text { 1997) }\end{array}$ & $\begin{array}{l}\text { Two analysts } \\
\text { using one of two } \\
\text { methods } \\
\text { (Accimap and } \\
\text { Root Cause } \\
\text { Analysis - RCA). } \\
\text { Three additional } \\
\text { researchers } \\
\text { reviewed the } \\
\text { outputs from the } \\
\text { analysts. A } \\
\text { validation review } \\
\text { was conducted } \\
\text { by a group of } \\
\text { domain experts } \\
\text { and subsequent } \\
\text { Accimap and } \\
\text { RCA models } \\
\text { were modified. }\end{array}$ & $\begin{array}{l}\text { Three human } \\
\text { factors experts } \\
\text { used the three } \\
\text { methods to } \\
\text { analyse the } \\
\text { incident and } \\
\text { collectively } \\
\text { reviewed their } \\
\text { outputs. An } \\
\text { experienced } \\
\text { outdoor activity } \\
\text { instructor } \\
\text { reviewed the } \\
\text { outcomes from } \\
\text { the analysis. }\end{array}$ \\
\hline
\end{tabular}


Table 3: Applying the framework to the 26 studies

\begin{tabular}{|c|c|c|c|c|c|c|c|c|c|}
\hline & 1 & 2 & 3 & 4 & 5 & 6 & 7 & 8 & 9 \\
\hline & Hopkins (2000) & $\begin{array}{l}\text { Woo and Vicente } \\
\text { (2003) }\end{array}$ & Ladkin (2005) & $\begin{array}{c}\text { Vicente and } \\
\text { Christopherson } \\
\text { (2006) }\end{array}$ & $\begin{array}{l}\text { Johnson and de } \\
\text { Almeida (2008) }\end{array}$ & $\begin{array}{c}\text { Cassano-Piche et } \\
\text { al. (2009) }\end{array}$ & Waterson (2009) & $\begin{array}{l}\text { Salmon et al } \\
(2010)\end{array}$ & $\begin{array}{l}\text { Salmon et al. } \\
\text { (2012) }\end{array}$ \\
\hline Outcomes & $\begin{array}{l}\text { Causal diagram of } \\
\text { Esso Gas Plant } \\
\text { Accident (Hopkins, } \\
2000, \text { p.122) }\end{array}$ & $\begin{array}{l}\text { Accimaps for each } \\
\text { outbreak; timelines; } \\
\text { Actormap of } \\
\text { counterproductive } \\
\text { interactions (Woo } \\
\text { and Vicente, 2003, p. } \\
\text { 266) }\end{array}$ & $\begin{array}{l}\text { Comparison and } \\
\text { critique of } \\
\text { Hopkin's } \\
\text { Accimap ; } \\
\text { Combination of } \\
\text { Accimap with } \\
\text { Why-Because- } \\
\text { Analysis (WBA) }\end{array}$ & $\begin{array}{l}\text { Accimaps for the } \\
\text { outbreak; } \\
\text { timeline }\end{array}$ & $\begin{array}{l}\text { Generic Actormap, } \\
\text { Conflict Map and } \\
\text { Accimap }\end{array}$ & $\begin{array}{l}\text { Accimaps for the } \\
\text { outbreak; timeline; } \\
\text { annotated 'conflict } \\
\text { map' showing poor } \\
\text { vertical integration } \\
\text { during the outbreak }\end{array}$ & $\begin{array}{l}\text { Adaptations of } \\
\text { the risk } \\
\text { management } \\
\text { framework } \\
\text { covering } \\
\text { c contributory } \\
\text { factors; cross- } \\
\text { level and whole } \\
\text { system } \\
\text { relationships. }\end{array}$ & $\begin{array}{l}\text { Accimap for the } \\
\text { incident; RCA } \\
\text { model (Davidson, } \\
\text { 2007) }\end{array}$ & $\begin{array}{l}\text { Accimap, HFACS } \\
\text { (Wiegmann and } \\
\text { Shappell, 2003) } \\
\text { and STAMP } \\
\text { (Leveson, 2004) } \\
\text { models. }\end{array}$ \\
\hline $\begin{array}{l}\text { Comparison } \\
\text { with other } \\
\text { models }\end{array}$ & None & None & $\begin{array}{l}\text { Comparison with } \\
\text { Accimap }\end{array}$ & None & $\begin{array}{l}\text { Comparison with } \\
\text { STAMP (Leveson, } \\
\text { 2003) }\end{array}$ & None & None & $\begin{array}{l}\text { Comparison with } \\
\text { RCA (Davidson, } \\
\text { 2007) }\end{array}$ & $\begin{array}{l}\text { Comparison with } \\
\text { HFACS and } \\
\text { STAMP }\end{array}$ \\
\hline $\begin{array}{l}\text { Levels of } \\
\text { analysis }\end{array}$ & $\begin{array}{l}5 \text { levels: Societal; } \\
\text { Government/ } \\
\text { Regulatory } \\
\text { System// } \\
\text { Company/ } \\
\text { Organisational/ } \\
\text { Physical Accident } \\
\text { Sequence }\end{array}$ & $\begin{array}{l}6 \text { levels: } \\
\text { Government/ } \\
\text { Regulatory } \\
\text { Bodies/Local } \\
\text { Government/ } \\
\text { Technical and } \\
\text { Operational } \\
\text { Management/ } \\
\text { Physical Processes } \\
\text { and Actor Activities/ } \\
\text { Equipment and } \\
\text { Surroundings }\end{array}$ & Not applicable & $\begin{array}{l}6 \text { levels: } \\
\text { Government/ } \\
\text { Regulatory } \\
\text { Bodies/Local } \\
\text { Government/ } \\
\text { Technical and } \\
\text { Operational } \\
\text { Management/ } \\
\text { Physical } \\
\text { Processes and } \\
\text { Actor Activities/ } \\
\text { Equipment and } \\
\text { Surroundings }\end{array}$ & $\begin{array}{l}6 \text { levels: } \\
\text { Government/ } \\
\text { Regulatory } \\
\text { Bodies/Local } \\
\text { Government/ } \\
\text { Technical and } \\
\text { Operational } \\
\text { Management/ } \\
\text { Physical Processes } \\
\text { and Actor } \\
\text { Activities/ } \\
\text { Equipment and } \\
\text { Surroundings }\end{array}$ & $\begin{array}{l}6 \text { levels: } \\
\text { Government/ } \\
\text { Regulatory } \\
\text { Bodies/Local } \\
\text { Government/ } \\
\text { Technical and } \\
\text { Operational } \\
\text { Management/ } \\
\text { s Physical Processes } \\
\text { and Actor } \\
\text { Activities/ } \\
\text { Equipment and } \\
\text { Surroundings }\end{array}$ & $\begin{array}{l}6 \text { levels: } \\
\text { Government/ } \\
\text { Regulatory / } \\
\text { Trust } \\
\text { Governance/ } \\
\text { Hospital } \\
\text { Management/ } \\
\text { Clinical } \\
\text { s Management/ } \\
\text { Equipment and } \\
\text { Surroundings }\end{array}$ & $\begin{array}{l}6 \text { levels: } \\
\text { Government/ } \\
\text { Regulatory / } \\
\text { Trust } \\
\text { Governance/ } \\
\text { Hospital } \\
\text { Management/ } \\
\text { Clinical } \\
\text { Management/ } \\
\text { Equipment and } \\
\text { Surroundings }\end{array}$ & $\begin{array}{l}6 \text { levels: } \\
\text { Government/ } \\
\text { Regulatory / } \\
\text { Trust } \\
\text { Governance/ } \\
\text { Hospital } \\
\text { Management/ } \\
\text { Clinical } \\
\text { Management/ } \\
\text { Equipment and } \\
\text { Surroundings }\end{array}$ \\
\hline
\end{tabular}


Table 3: Applying the framework to the 26 studies

\begin{tabular}{|c|c|c|c|c|c|c|c|c|c|}
\hline & 1 & 2 & 3 & 4 & 5 & 6 & 7 & 8 & 9 \\
\hline & Hopkins (2000) & $\begin{array}{l}\text { Woo and Vicente } \\
\text { (2003) }\end{array}$ & Ladkin (2005) & $\begin{array}{c}\text { Vicente and } \\
\text { Christopherson } \\
(2006)\end{array}$ & $\begin{array}{l}\text { Johnson and de } \\
\text { Almeida (2008) }\end{array}$ & $\begin{array}{l}\text { Cassano-Piche et } \\
\text { al. (2009) }\end{array}$ & Waterson (2009) & $\begin{array}{c}\text { Salmon et al } \\
(2010)\end{array}$ & $\begin{array}{l}\text { Salmon et al. } \\
\text { (2012) }\end{array}$ \\
\hline $\begin{array}{l}\text { Causal } \\
\text { factors }\end{array}$ & $\begin{array}{l}27 \text { factors, most } \\
\text { organised at the } \\
\text { 'organisational' } \\
\text { level of analysis }\end{array}$ & $\begin{array}{l}\text { Walkerton - } 33 \\
\text { factors; } \\
\text { North Battleton - } 53 \\
\text { factors. Mostly evenly } \\
\text { distributed for both } \\
\text { outbreaks }\end{array}$ & Not applicable & 33 factors & 33 factors & 43 factors & $\begin{array}{l}7 \text { contributory } \\
\text { factors; } 3 \\
\text { hypothesised } \\
\text { cross-level } \\
\text { relationships and } \\
3 \text { whole system } \\
\text { relationships }\end{array}$ & 42 factors & 61 factors \\
\hline $\begin{array}{l}\text { Changes to } \\
\text { standard } \\
\text { Accimap }\end{array}$ & $\begin{array}{l}\text { Small deviation } \\
\text { from original } \\
\text { formulation }\end{array}$ & No major changes & Not applicable & $\begin{array}{l}\text { No major } \\
\text { changes }\end{array}$ & $\begin{array}{l}\text { Small deviation } \\
\text { from original } \\
\text { formulation (no } \\
\text { distinction drawn } \\
\text { between indirect } \\
\text { and direct causes) }\end{array}$ & $\begin{array}{l}\text { No major changes; } \\
\text { addition of 'critical } \\
\text { event' factor }\end{array}$ & $\begin{array}{l}\text { Use of the Risk } \\
\text { Management } \\
\text { Framework and } \\
\text { not standard } \\
\text { Accimap format }\end{array}$ & $\begin{array}{l}\text { Small deviation } \\
\text { from original } \\
\text { formulation (no } \\
\text { distinction drawn } \\
\text { between indirect } \\
\text { and direct } \\
\text { causes) }\end{array}$ & $\begin{array}{l}\text { Small deviation } \\
\text { from original } \\
\text { formulation (no } \\
\text { distinction drawn } \\
\text { between indirect } \\
\text { and direct } \\
\text { causes) }\end{array}$ \\
\hline Other details & $\begin{array}{l}\text { Relatively simple } \\
\text { Accimap; use of } \\
\text { arrows to indicate } \\
\text { cross-level } \\
\text { causality }\end{array}$ & $\begin{array}{l}\text { Integration of 'logic } \\
\text { gates' in the Accimap }\end{array}$ & $\begin{array}{l}\text { Graphical } \\
\text { representation of } \\
\text { WBA and } \\
\text { Accimap }\end{array}$ & $\begin{array}{l}\text { Integration of } \\
\text { fault trees in the } \\
\text { Accimap. Attempt } \\
\text { to test some of } \\
\text { the 'predictions' } \\
\text { made by } \\
\text { Rasmussen's } \\
\text { (1997) Risk } \\
\text { Management } \\
\text { Framework }\end{array}$ & $\begin{array}{l}\text { Actormap is used } \\
\text { as the basis for the } \\
\text { Accimap. } \\
\text { Conflictmap is used } \\
\text { to illustrate inter- } \\
\text { relationships } \\
\text { between actors, } \\
\text { decisions and other } \\
\text { influences leading } \\
\text { up to the explosion }\end{array}$ & $\begin{array}{l}\text { Attempt to test } \\
\text { some of the } \\
\text { 'predictions' made } \\
\text { d by Rasmussen's } \\
\text { (1997) Risk } \\
\text { Management } \\
\text { Framework }\end{array}$ & $\begin{array}{l}\text { Attempt to } \\
\text { hypothesise } \\
\text { difference causal } \\
\text { relationships } \\
\text { within the } \\
\text { hospital. No } \\
\text { identification of } \\
\text { specific causal } \\
\text { factors. }\end{array}$ & $\begin{array}{l}\text { Attempt to test } \\
\text { some of the } \\
\text { 'predictions' } \\
\text { made by } \\
\text { Rasmussen's } \\
\text { (1997) Risk } \\
\text { Management } \\
\text { Framework; } \\
\text { Comparison with } \\
\text { RCA outputs }\end{array}$ & $\begin{array}{l}\text { Comparison } \\
\text { between three } \\
\text { methods; } \\
\text { recommendation } \\
\text { that Accimaps } \\
\text { include a domain } \\
\text { specific } \\
\text { taxonomy of } \\
\text { failure modes }\end{array}$ \\
\hline
\end{tabular}


Table 3: Applying the framework to the 26 studies

\begin{tabular}{|c|c|c|c|c|c|c|c|}
\hline & 10 & 11 & 12 & 13 & 14 & 15 & 16 \\
\hline & Jenkins et al. (2010) & Jenkins et al. (2011) & Le Coze (2010) & Andersson (2010) & Branford (2011) & Debrincat et al. (2013) & Salmon et al. (2013) \\
\hline $\begin{array}{l}\text { Context of } \\
\text { use }\end{array}$ & $\begin{array}{l}\text { Policing - Stockwell } \\
\text { (2005) shooting }\end{array}$ & $\begin{array}{l}\text { Policing - Stockwell } \\
\text { (2005) shooting }\end{array}$ & $\begin{array}{l}\text { Manufacturing - Accident } \\
\text { in a dynamite factory at } \\
\text { Billy Berclau, France } \\
(2003)\end{array}$ & $\begin{array}{l}\text { Nuclear - 'Out-of-The } \\
\text { Loop'(OOTL) } \\
\text { performance problem } \\
\text { in automation }\end{array}$ & $\begin{array}{l}\text { Aviation - Analysis of } \\
\text { the Überlingen mid-air } \\
\text { collision }\end{array}$ & $\begin{array}{l}\text { Aviation - Crash of Royal } \\
\text { Australian Navy King } \\
\text { Helicopter (2005) }\end{array}$ & $\begin{array}{l}\text { Rail - Accident at level } \\
\text { crossing involving a } \\
\text { vehicle at Kerang, } \\
\text { Australia (2007) }\end{array}$ \\
\hline $\begin{array}{l}\text { Goals and } \\
\text { objectives }\end{array}$ & $\begin{array}{l}\text { Exploration of the } \\
\text { interdependencies } \\
\text { and between actions, } \\
\text { omissions and } \\
\text { decisions which led } \\
\text { up to the shooting } \\
\text { incident }\end{array}$ & $\begin{array}{l}\text { Builds on Jenkins et } \\
\text { al. (2010), but focuses } \\
\text { on individual factors } \\
\text { (flow of alerts, } \\
\text { information, goals, } \\
\text { task and procedures } \\
\text { (Jenkins et al. 2010, } \\
\text { p. 103). }\end{array}$ & $\begin{array}{l}\text { Aim is to illustrate trends in } \\
\text { safety auditing and } \\
\text { accident investigation with } \\
\text { an emphasis on targeting } \\
\text { organisational factors (Le } \\
\text { Coze, 2010, p. 80) }\end{array}$ & $\begin{array}{l}\text { Exploration of how } \\
\text { Accimaps can be used } \\
\text { to provide a holistic } \\
\text { overview of automation } \\
\text { related problems }\end{array}$ & $\begin{array}{l}\text { Demonstration of the } \\
\text { ('big picture') benefits of } \\
\text { the Accimap approach } \\
\text { towards systemic } \\
\text { accident analysis }\end{array}$ & $\begin{array}{l}\text { Aim is to determine which } \\
\text { tools can assist with } \\
\text { achieving organisational } \\
\text { improvement within the } \\
\text { aviation industry, particularly } \\
\text { in terms of identifying and } \\
\text { visualising organisational } \\
\text { factors. }\end{array}$ & $\begin{array}{l}\text { Aim is to examine the } \\
\text { level crossing system } \\
\text { in which the accident } \\
\text { took place and } \\
\text { understand the actions } \\
\text { of the individual truck } \\
\text { driver in crossing the } \\
\text { track in the presence } \\
\text { of an oncoming train }\end{array}$ \\
\hline $\begin{array}{l}\text { Theoretical } \\
\text { background }\end{array}$ & $\begin{array}{l}\text { Sociotechnical } \\
\text { systems theory; } \\
\text { Rasmussen's risk } \\
\text { management } \\
\text { framework (1997) }\end{array}$ & $\begin{array}{l}\text { Sociotechnical } \\
\text { systems theory; } \\
\text { Rasmussen's risk } \\
\text { management } \\
\text { framework (1997). } \\
\text { Use of a number of } \\
\text { theoretical } \\
\text { approaches to } \\
\text { analyse the incident } \\
\text { (e.g., situational } \\
\text { awareness, Endsley, }\end{array}$ & $\begin{array}{l}\text { Safety engineering and } \\
\text { management; human and } \\
\text { social sciences }\end{array}$ & $\begin{array}{l}\text { Human factors, safety } \\
\text { science }\end{array}$ & $\begin{array}{l}\text { Rasmussen's model of } \\
\text { boundaries of } \\
\text { acceptable and } \\
\text { unacceptable } \\
\text { performance } \\
\text { (Rasmussen, 1997) }\end{array}$ & $\begin{array}{l}\text { Systemic accident analysis; } \\
\text { Human factors approach } \\
\text { (James Reason) }\end{array}$ & $\begin{array}{l}\text { Sociotechnical } \\
\text { systems theory; } \\
\text { Rasmussen's risk } \\
\text { management } \\
\text { framework (1997). Use } \\
\text { of a number of } \\
\text { theoretical approaches } \\
\text { to analyse the incident } \\
\text { (e.g., schema theory, } \\
\text { Neisser, 1976) }\end{array}$ \\
\hline
\end{tabular}


Table 3: Applying the framework to the 26 studies

\begin{tabular}{|c|c|c|c|c|c|c|c|}
\hline & 10 & 11 & 12 & 13 & 14 & 15 & 16 \\
\hline & Jenkins et al. (2010) & Jenkins et al. (2011) & Le Coze (2010) & Andersson (2010) & Branford (2011) & Debrincat et al. (2013) & Salmon et al. (2013) \\
\hline & & $\begin{array}{l}\text { 1995; schema theory, } \\
\text { Neisser, 1976, } \\
\text { decision-ladder, } \\
\text { Rasmussen, 1974) }\end{array}$ & & & & & \\
\hline Procedure & $\begin{array}{l}\text { One human factors } \\
\text { practitioner (lead } \\
\text { author) carried out } \\
\text { the analysis, co- } \\
\text { authors (3) checked } \\
\text { and validated the } \\
\text { analysis }\end{array}$ & $\begin{array}{l}\text { Lead author } \\
\text { generated the models, } \\
\text { these were then } \\
\text { validated by the } 4 \text { co- } \\
\text { authors }\end{array}$ & $\begin{array}{l}\text { No explicit procedure } \\
\text { described for the Accimap, } \\
\text { but steps in the analysis of } \\
\text { the accident described } \\
\text { (e.g., building up detailed } \\
\text { chronology, identifying } \\
\text { barriers, investigating } \\
\text { business environment) }\end{array}$ & $\begin{array}{l}\text { No explicit mention of } \\
\text { procedure }\end{array}$ & $\begin{array}{l}\text { No explicit procedure } \\
\text { described for the } \\
\text { Accimap }\end{array}$ & $\begin{array}{l}\text { No explicit procedure } \\
\text { described for the Accimap }\end{array}$ & $\begin{array}{l}\text { Three human factors } \\
\text { experts initially } \\
\text { discussed the findings } \\
\text { from the investigation } \\
\text { report; one expert } \\
\text { build the Accimap and } \\
\text { two others reviewed } \\
\text { the results; the } \\
\text { Accimap was refined } \\
\text { through discussion } \\
\text { and reviewed by two } \\
\text { rail safety practitioners } \\
\text { and the lead } \\
\text { investigator from the } \\
\text { official investigation } \\
\text { team }\end{array}$ \\
\hline Outcomes & $\begin{array}{l}\text { Accimap for the } \\
\text { incident, 'time } \\
\text { stamped' and coded } \\
\text { according to time } \\
\text { phase, causal } \\
\text { relationships and } \\
\text { 'weak' causal links }\end{array}$ & $\begin{array}{l}\text { As Jenkins et al. } \\
\text { (2011), but with } \\
\text { additional analysis } \\
\text { based on schema } \\
\text { theory, decision } \\
\text { ladders }\end{array}$ & Accimap of the accident & $\begin{array}{l}\text { Accimap describing the } \\
\text { factors influencing } \\
\text { OOTL performance } \\
\text { during use of an } \\
\text { automatic turbine } \\
\text { system in a nuclear } \\
\text { plant }\end{array}$ & Accimap of the accident & $\begin{array}{l}\text { Accimap of the accident and } \\
\text { development of hybrid model } \\
\text { based on Reason's (1990) } \\
\text { Swiss Cheese model }\end{array}$ & $\begin{array}{l}\text { Accimap for the } \\
\text { accident with } \\
\text { additional analyses } \\
\text { applying Schema } \\
\text { theory (Neisser } \\
\text { perceptual cycle - } \\
\text { Neisser, 1976) in }\end{array}$ \\
\hline
\end{tabular}


Table 3: Applying the framework to the 26 studies

\begin{tabular}{|c|c|c|c|c|c|c|c|}
\hline & 10 & 11 & 12 & 13 & 14 & 15 & 16 \\
\hline & Jenkins et al. (2010) & Jenkins et al. (2011) & Le Coze (2010) & Andersson (2010) & Branford (2011) & Debrincat et al. (2013) & Salmon et al. (2013) \\
\hline & & & & & & & $\begin{array}{l}\text { order to account for } \\
\text { the truck driver's } \\
\text { behaviour }\end{array}$ \\
\hline $\begin{array}{l}\text { Comparison } \\
\text { with other } \\
\text { models }\end{array}$ & None & None & None & None & None & $\begin{array}{l}\text { Comparison with Swiss } \\
\text { Cheese Model }\end{array}$ & None \\
\hline $\begin{array}{l}\text { Levels of } \\
\text { analysis }\end{array}$ & $\begin{array}{l}6 \text { levels: } \\
\text { Government Policy } \\
\text { and } \\
\text { Budgeting/Regulatory } \\
\text { Bodies and } \\
\text { associations/Local } \\
\text { Area Government, } \\
\text { Planning and } \\
\text { Budgeting, Company } \\
\text { Management } \\
\text { (strategic } \\
\text { command)/Technical } \\
\text { and Operational } \\
\text { management } \\
\text { (Tactical Command)/ } \\
\text { Physical Processes } \\
\text { and Actor Activities/ } \\
\text { Equipment and }\end{array}$ & $\begin{array}{l}\text { As Jenkins et al. } \\
\text { (2011) }\end{array}$ & $\begin{array}{l}6 \text { levels: } \\
\text { Society, } \\
\text { market/Government } \\
\text { regulatory system/ } \\
\text { Company/ Site } \\
\text { management/ Operational } \\
\text { management/Shop floor } \\
\text { and installations }\end{array}$ & $\begin{array}{l}4 \text { levels: Company } \\
\text { management/Technical } \\
\text { and operational } \\
\text { management/ Physical } \\
\text { Processes and } \\
\text { operator activities/ } \\
\text { Equipment and } \\
\text { Surroundings }\end{array}$ & $\begin{array}{l}4 \text { levels: } \\
\text { External/Organisational/ } \\
\text { Physical and Actor } \\
\text { Events, Processes and } \\
\text { Conditions }\end{array}$ & $\begin{array}{l}\text { No explicit mention of levels } \\
\text { of analysis }\end{array}$ & $\begin{array}{l}6 \text { levels: } \\
\text { Government/ } \\
\text { Regulatory / Trust } \\
\text { Governance/ Hospital } \\
\text { Management/ Clinical } \\
\text { Management/ } \\
\text { Equipment and } \\
\text { Surroundings }\end{array}$ \\
\hline
\end{tabular}


Table 3: Applying the framework to the 26 studies

\begin{tabular}{|c|c|c|c|c|c|c|c|}
\hline & 10 & 11 & 12 & 13 & 14 & 15 & 16 \\
\hline & Jenkins et al. (2010) & Jenkins et al. (2011) & Le Coze (2010) & Andersson (2010) & Branford (2011) & Debrincat et al. (2013) & Salmon et al. (2013) \\
\hline & Surroundings & & & & & & \\
\hline & 43 factors & $\begin{array}{l}\text { As Jenkins et al. } \\
\text { (2011) }\end{array}$ & 36 factors & 21 factors & 29 factors & 26 factors & 36 factors \\
\hline $\begin{array}{l}\text { Changes to } \\
\text { standard } \\
\text { Accimap }\end{array}$ & $\begin{array}{l}\text { Addition of 'time } \\
\text { stamp' and coding } \\
\text { according to time } \\
\text { phase, causal } \\
\text { relationships and } \\
\text { 'weak' causal links }\end{array}$ & $\begin{array}{l}\text { As Jenkins et al. } \\
\text { (2011) }\end{array}$ & $\begin{array}{l}\text { Labels covering the levels } \\
\text { of analysis within the } \\
\text { overall system changed }\end{array}$ & $\begin{array}{l}\text { Annotation of Accimap } \\
\text { with 'paths' which } \\
\text { describe factors likely } \\
\text { to contribute to OOTL } \\
\text { problems }\end{array}$ & $\begin{array}{l}\text { Simplification of system } \\
\text { levels ( } 4 \text { as compared } \\
\text { to standard } 6 \text { ), shading } \\
\text { used to highlight the } \\
\text { role played by the air } \\
\text { traffic controller in the } \\
\text { accident and the } \\
\text { influences within the } \\
\text { overall system upon } \\
\text { their actions and } \\
\text { decisions }\end{array}$ & $\begin{array}{l}\text { No explicit labelling of system } \\
\text { levels of analysis; Accimap } \\
\text { simplified with causal } \\
\text { connection numbered ; levels } \\
\text { (e.g., safety culture, working } \\
\text { environment) distributed } \\
\text { across the Accimap }\end{array}$ & $\begin{array}{l}\text { No major changes to } \\
\text { the standard format }\end{array}$ \\
\hline Other details & $\begin{array}{l}\text { Attempt to test some } \\
\text { of the 'predictions' } \\
\text { made by } \\
\text { Rasmussen's (1997) } \\
\text { Risk Management } \\
\text { Framework; Use of }\end{array}$ & $\begin{array}{l}\text { Accimap used as a } \\
\text { basis for further } \\
\text { application of theory in } \\
\text { order to understand } \\
\text { the decision-making } \\
\text { process of individuals }\end{array}$ & $\begin{array}{l}\text { Study places emphasis on } \\
\text { the role played by changes } \\
\text { within the history of the } \\
\text { company and how this } \\
\text { ultimately shaped the } \\
\text { course of the accident }\end{array}$ & $\begin{array}{l}\text { Accimap is partly used } \\
\text { to identify function } \\
\text { allocation problems } \\
\text { and assess likelihood } \\
\text { of occurrence of } \\
\text { cognitive error (e.g., }\end{array}$ & $\begin{array}{l}\text { Accimap is partly used } \\
\text { to illustrate the } \\
\text { influence of the broad } \\
\text { sociotechnical context } \\
\text { in aviation safety }\end{array}$ & $\begin{array}{l}\text { Accimap records casual } \\
\text { factors across the whole of } \\
\text { the system; deviates from } \\
\text { standard format and had a } \\
\text { 'freeform' structure }\end{array}$ & $\begin{array}{l}\text { Additional analysis } \\
\text { using schema theory } \\
\text { in order to embellish } \\
\text { the systems analysis } \\
\text { with an individual, } \\
\text { psychological account }\end{array}$ \\
\hline
\end{tabular}


Table 3: Applying the framework to the 26 studies

\begin{tabular}{|c|c|c|c|c|c|c|}
\hline 10 & 11 & 12 & 13 & 14 & 15 & 16 \\
\hline Jenkins et al. (2010) & Jenkins et al. (2011) & Le Coze (2010) & Andersson (2010) & Branford (2011) & Debrincat et al. (2013) & Salmon et al. (2013) \\
\hline $\begin{array}{l}\text { decision-ladders } \\
\text { (Rasmussen, 1974) } \\
\text { to depict allocation of } \\
\text { function between } \\
\text { personnel resources } \\
\text { during the shooting }\end{array}$ & during the incident & & divided attention) & & & of the accident \\
\hline
\end{tabular}


Table 3: Applying the framework to the 26 studies

\begin{tabular}{|c|c|c|c|c|c|c|c|c|}
\hline & 17 & 18 & 19 & 20 & 21 & 22 & 23 & 24 \\
\hline & $\begin{array}{l}\text { Underwood and } \\
\text { Waterson (2014) }\end{array}$ & $\begin{array}{c}\text { Scott-Parker et al. } \\
(2014)\end{array}$ & Lei et al. (2014) & Trotter et al. (2014) & $\begin{array}{l}\text { Harvey and } \\
\text { Stanton (2014) }\end{array}$ & Salmon et al. (2014) & $\begin{array}{l}\text { Tabinzadeh and } \\
\text { Meshkati (2015) }\end{array}$ & Fan et al. (2015) \\
\hline $\begin{array}{l}\text { Context of } \\
\text { use }\end{array}$ & $\begin{array}{l}\text { Transport (Rail) - } \\
\text { Grayrigg (UK) } \\
\text { accident involving } \\
\text { train derailment } \\
\text { (2007) }\end{array}$ & $\begin{array}{l}\text { Transport (Road) - } \\
\text { accidents involving } \\
\text { young drivers }\end{array}$ & $\begin{array}{l}\text { Aviation - crash of } \\
\text { flight demonstrator } \\
\text { (China - February } \\
\text { 2009) and unmanned } \\
\text { aircraft (US O April } \\
\text { 2006) }\end{array}$ & $\begin{array}{l}\text { Outdoor Recreation and } \\
\text { Space Flight - } \\
\text { Mangatepopo Gorge } \\
\text { Incident (2008) - Apollo } \\
\text { 13LM Consumables } \\
\text { Incident (April, 1970) }\end{array}$ & $\begin{array}{l}\text { Aviation (Military) - } \\
\text { Hawk Jet Missile } \\
\text { Simulation }\end{array}$ & $\begin{array}{l}\text { Emergency Response } \\
\text { (Fire) - Murrindindi } \\
\text { Bushfire (February, } \\
\text { 2009) }\end{array}$ & $\begin{array}{l}\text { Oil and Gas - BP } \\
\text { Deepwater Horizon } \\
\text { blowout (2010) }\end{array}$ & $\begin{array}{l}\text { Civil Engineering - } \\
\text { Yangmingtan Bridge } \\
\text { Collapse (August, } \\
\text { 2012) }\end{array}$ \\
\hline $\begin{array}{l}\text { Goals and } \\
\text { objectives }\end{array}$ & $\begin{array}{l}\text { Comparison } \\
\text { between three } \\
\text { difference accident } \\
\text { analysis models } \\
\text { (Accimap, STAMP, } \\
\text { and Australian } \\
\text { Transport Safety } \\
\text { Bureau model - } \\
\text { ATSB) }\end{array}$ & $\begin{array}{l}\text { Use of Accimaps to } \\
\text { demonstrate the } \\
\text { value of applying as } \\
\text { systems approach to } \\
\text { the causes of } \\
\text { accidents involving } \\
\text { young drivers }\end{array}$ & $\begin{array}{l}\text { Development of } \\
\text { 'AcciTree' - the main } \\
\text { being to combine the } \\
\text { graphical } \\
\text { representation } \\
\text { available within an } \\
\text { Accimap with the } \\
\text { error taxonomy } \\
\text { available in HFACS }\end{array}$ & $\begin{array}{l}\text { Examination of systems } \\
\text { related factors in the form } \\
\text { of 'Impromaps' which } \\
\text { were involved in } \\
\text { improvisation incidents } \\
\text { leading to positive and } \\
\text { negative accident } \\
\text { outcomes }\end{array}$ & $\begin{array}{l}\text { Use of case study } \\
\text { to demonstrate and } \\
\text { illustrate a set of } \\
\text { core challenges for } \\
\text { real-world systems- } \\
\text { of-systems }\end{array}$ & $\begin{array}{l}\text { Testing the usefulness } \\
\text { of the Accimap } \\
\text { approach for examining } \\
\text { the systemic } \\
\text { characteristics of } \\
\text { disaster response }\end{array}$ & $\begin{array}{l}\text { Analysis of main } \\
\text { contributing causes } \\
\text { of system failure and } \\
\text { interactions of key } \\
\text { decision-makers and } \\
\text { stakeholders }\end{array}$ & $\begin{array}{l}\text { Analysis of system } \\
\text { wide failures leading } \\
\text { up to bridge collapse }\end{array}$ \\
\hline $\begin{array}{l}\text { Theoretical } \\
\text { background }\end{array}$ & $\begin{array}{l}\text { Safety Science; } \\
\text { Human Factors and } \\
\text { Ergonomics }\end{array}$ & $\begin{array}{l}\text { Sociotechnical } \\
\text { systems theory; } \\
\text { Rasmussen's risk } \\
\text { management } \\
\text { framework (1997) }\end{array}$ & $\begin{array}{l}\text { Safety Science; } \\
\text { Human Factors and } \\
\text { Ergonomics }\end{array}$ & $\begin{array}{l}\text { Sociotechnical systems } \\
\text { theory; Rasmussen's risk } \\
\text { management framework } \\
\text { (1997) }\end{array}$ & $\begin{array}{l}\text { Safety science; } \\
\text { human factors and } \\
\text { ergonomics }\end{array}$ & $\begin{array}{l}\text { Sociotechnical systems } \\
\text { theory; Rasmussen's } \\
\text { risk management } \\
\text { framework (1997) }\end{array}$ & $\begin{array}{l}\text { Safety Science; } \\
\text { Sociotechnical } \\
\text { systems theory; } \\
\text { Rasmussen's risk } \\
\text { management } \\
\text { framework (1997) }\end{array}$ & $\begin{array}{l}\text { Engineering; } \\
\text { Rasmussen's risk } \\
\text { management } \\
\text { framework (1997) }\end{array}$ \\
\hline
\end{tabular}


Table 3: Applying the framework to the 26 studies

\begin{tabular}{|c|c|c|c|c|c|c|c|c|}
\hline & 17 & 18 & 19 & 20 & 21 & 22 & 23 & 24 \\
\hline & $\begin{array}{l}\text { Underwood and } \\
\text { Waterson (2014) }\end{array}$ & $\begin{array}{c}\text { Scott-Parker et al. } \\
(2014)\end{array}$ & Lei et al. (2014) & Trotter et al. (2014) & $\begin{array}{l}\text { Harvey and } \\
\text { Stanton (2014) }\end{array}$ & Salmon et al. (2014) & $\begin{array}{l}\text { Tabinzadeh and } \\
\text { Meshkati (2015) }\end{array}$ & Fan et al. (2015) \\
\hline Procedure & $\begin{array}{l}\text { Procedure followed } \\
\text { the outline guidance } \\
\text { provided by } \\
\text { Svedung and } \\
\text { Rasmussen, (2002). } \\
\text { Coding using } \\
\text { qualitative data } \\
\text { software of accident } \\
\text { investigation report: } \\
\text { (1) Topography of } \\
\text { the accident scene; } \\
\text { (2) decision./actions } \\
\text { taken by actors; (3) } \\
\text { direct/indirect causal } \\
\text { consequence; and, } \\
\text { (4) preconditions } \\
\text { requiring no further } \\
\text { evaluation }\end{array}$ & No explicit details & No explicit details & $\begin{array}{l}\text { One human factors } \\
\text { expert competed the } \\
\text { analysis, a second expert } \\
\text { checked it and reviewed } \\
\text { the 'Impromaps' }\end{array}$ & No explicit details & $\begin{array}{l}2 \text { human factors } \\
\text { experts generated the } \\
\text { Accimap; Accimap was } \\
\text { then validated by three } \\
\text { subject matter experts }\end{array}$ & No explicit details & $\begin{array}{l}\text { Coding using } \\
\text { qualitative software } \\
\text { based on multimedia } \\
\text { sources (newspaper } \\
\text { reports, we-based } \\
\text { materials, videos - } \\
\text { no official report } \\
\text { available) }\end{array}$ \\
\hline Outcomes & $\begin{array}{l}\text { Accimap of the } \\
\text { accident }\end{array}$ & $\begin{array}{l}\text { Actormap; } \\
\text { Accimap (causal } \\
\text { factors); } \\
\text { Accimap } \\
\text { (countermeasures) }\end{array}$ & $\begin{array}{l}\text { AcciTree models of } \\
\text { both accidents }\end{array}$ & $\begin{array}{l}\text { Impromaps for both } \\
\text { incidents }\end{array}$ & $\begin{array}{l}\text { Accimap of the } \\
\text { subsystems } \\
\text { involved with the } \\
\text { Hawk Jet Missile } \\
\text { System-of-Systems } \\
\text { (SoS) }\end{array}$ & Accimap of bushfire & $\begin{array}{l}\text { Accimap of the } \\
\text { Deepwater Horizon } \\
\text { blowout }\end{array}$ & $\begin{array}{l}\text { Accimap of the } \\
\text { Yangmingtan Bridge } \\
\text { Collapse }\end{array}$ \\
\hline
\end{tabular}


Table 3: Applying the framework to the 26 studies

\begin{tabular}{|c|c|c|c|c|c|c|c|c|}
\hline & 17 & 18 & 19 & 20 & 21 & 22 & 23 & 24 \\
\hline & $\begin{array}{l}\text { Underwood and } \\
\text { Waterson (2014) }\end{array}$ & $\begin{array}{c}\text { Scott-Parker et al. } \\
(2014)\end{array}$ & Lei et al. (2014) & Trotter et al. (2014) & $\begin{array}{l}\text { Harvey and } \\
\text { Stanton (2014) }\end{array}$ & Salmon et al. (2014) & $\begin{array}{l}\text { Tabinzadeh and } \\
\text { Meshkati (2015) }\end{array}$ & Fan et al. (2015) \\
\hline $\begin{array}{l}\text { Comparison } \\
\text { with other } \\
\text { models }\end{array}$ & $\begin{array}{l}\text { Australian Transport } \\
\text { Safety Bureau } \\
\text { (ATSB) model, and } \\
\text { STAMP (Leveson, } \\
\text { 2003) }\end{array}$ & None & $\begin{array}{l}\text { HFACS, SHEL } \\
\text { (Edwards, 1988) }\end{array}$ & None & None & None & None & None \\
\hline $\begin{array}{l}\text { Levels of } \\
\text { analysis }\end{array}$ & $\begin{array}{l}6 \text { levels: } \\
\text { Government/ } \\
\text { Regulatory } \\
\text { Bodies/Local } \\
\text { Government/ } \\
\text { Technical and } \\
\text { Operational } \\
\text { Management/ } \\
\text { Physical Processes } \\
\text { and Actor Activities/ } \\
\text { Equipment and } \\
\text { Surroundings }\end{array}$ & $\begin{array}{l}6 \text { levels: } \\
\text { Government/ } \\
\text { Regulatory } \\
\text { Bodies/Local } \\
\text { Government/ } \\
\text { Technical and } \\
\text { Operational } \\
\text { Management/ } \\
\text { Physical Processes } \\
\text { and Actor Activities/ } \\
\text { Equipment and } \\
\text { Surroundings }\end{array}$ & No applicable & $\begin{array}{l}6 \text { levels: } \\
\text { Government/ Regulatory } \\
\text { Bodies/Local } \\
\text { Government/ } \\
\text { Technical and } \\
\text { Operational } \\
\text { Management/ } \\
\text { Physical Processes and } \\
\text { Actor Activities/ } \\
\text { Equipment and } \\
\text { Surroundings }\end{array}$ & $\begin{array}{l}6 \text { levels: } \\
\text { Government// } \\
\text { Regulatory } \\
\text { Bodies/Local } \\
\text { Government/ } \\
\text { Technical and } \\
\text { Operational } \\
\text { Management/ } \\
\text { Physical Processes } \\
\text { and Actor } \\
\text { Activities/ } \\
\text { Equipment and } \\
\text { Surroundings }\end{array}$ & $\begin{array}{l}6 \text { levels: } \\
\text { Government// } \\
\text { Regulatory } \\
\text { Bodies/Local } \\
\text { Government/ } \\
\text { Technical and } \\
\text { Operational } \\
\text { Management/ } \\
\text { Physical Processes } \\
\text { and Actor Activities/ } \\
\text { Equipment and } \\
\text { Surroundings }\end{array}$ & $\begin{array}{l}6 \text { levels: } \\
\text { Government/ } \\
\text { Regulatory } \\
\text { Bodies/Local } \\
\text { Government/ } \\
\text { Technical and } \\
\text { Operational } \\
\text { Management/ } \\
\text { Physical Processes } \\
\text { and Actor Activities/ } \\
\text { Equipment and } \\
\text { Surroundings }\end{array}$ & $\begin{array}{l}6 \text { levels: } \\
\text { Government/ } \\
\text { Regulatory Agencies } \\
\text { and } \\
\text { Associations/Compa } \\
\text { ny/ } \\
\text { Management/Staff/ } \\
\text { Physical Accident } \\
\text { Sequence }\end{array}$ \\
\hline $\begin{array}{l}\text { Causal } \\
\text { factors }\end{array}$ & 63 factors & $\begin{array}{l}\text { Actormap - } 38 \text { actor } \\
\text { Accimap (causal } \\
\text { factors) - } 36 \text { factors } \\
\text { Accimap } \\
\text { (countermeasures) - } \\
6 \text { factors }\end{array}$ & Not applicable & $\begin{array}{l}\text { Mangatepopo Gorge } \\
\text { Incident - } 35 \text { factors } \\
\text { Apollo } 13 L M \text { Incident - } \\
64 \text { factors }\end{array}$ & 16 factors & 71 factors & 66 factors & 21 factors \\
\hline
\end{tabular}


Table 3: Applying the framework to the 26 studies

\begin{tabular}{|c|c|c|c|c|c|c|c|c|}
\hline & 17 & 18 & 19 & 20 & 21 & 22 & 23 & 24 \\
\hline & $\begin{array}{l}\text { Underwood and } \\
\text { Waterson (2014) }\end{array}$ & $\begin{array}{c}\text { Scott-Parker et al. } \\
(2014)\end{array}$ & Lei et al. (2014) & Trotter et al. (2014) & $\begin{array}{l}\text { Harvey and } \\
\text { Stanton (2014) }\end{array}$ & Salmon et al. (2014) & $\begin{array}{l}\text { Tabinzadeh and } \\
\text { Meshkati (2015) }\end{array}$ & Fan et al. (2015) \\
\hline $\begin{array}{l}\text { Changes to } \\
\text { standard } \\
\text { Accimap }\end{array}$ & $\begin{array}{l}\text { Addition of colour } \\
\text { coding for factors }\end{array}$ & None & $\begin{array}{l}\text { New 'hybrid' model - } \\
\text { AcciTree (Accimap + } \\
\text { HFACS) }\end{array}$ & $\begin{array}{l}\text { Addition of categories } \\
\text { covering causal factors } \\
\text { within one pf the } \\
\text { Impromaps (e.g., factors } \\
\text { such as experience, } \\
\text { organisational culture) }\end{array}$ & $\begin{array}{l}\text { Annotation of SoS } \\
\text { aspects of the } \\
\text { Hawk Missile } \\
\text { System }\end{array}$ & None & None & $\begin{array}{l}\text { Focus on company } \\
\text { failures }\end{array}$ \\
\hline Other details & & $\begin{array}{l}\text { Use of Accimap to } \\
\text { organise previous } \\
\text { research findings } \\
\text { from the literature on } \\
\text { young drivers and } \\
\text { accidents, alongside } \\
\text { details of possible } \\
\text { countermeasures } \\
\text { which could be used } \\
\text { to reduce accidents } \\
\text { in this target group }\end{array}$ & $\begin{array}{l}\text { Argument that the } \\
\text { reliability of the } \\
\text { original Accimap } \\
\text { format is improved } \\
\text { with AcciTrees (due } \\
\text { to inclusion of } \\
\text { HFACS taxonomy) }\end{array}$ & $\begin{array}{l}\text { Modification of Accimap } \\
\text { to cover improvisation } \\
\text { incidents }\end{array}$ & & $\begin{array}{l}\text { Test of the applicability } \\
\text { of the Accimap } \\
\text { approach within } \\
\text { emergency response }\end{array}$ & & - \\
\hline
\end{tabular}


Table 3: Applying the framework to the 26 studies

\begin{tabular}{|c|c|c|}
\hline & 25 & 26 \\
\hline & Newman and Goode (2015) & Stefanova et al (2015) \\
\hline $\begin{array}{l}\text { Context of } \\
\text { use }\end{array}$ & $\begin{array}{l}\text { Transport (Road) - Crashes } \\
\text { involving road freight vehicles }\end{array}$ & $\begin{array}{l}\text { Transport (Rail) - Pedestrian } \\
\text { safety at level crossings }\end{array}$ \\
\hline $\begin{array}{l}\text { Goals and } \\
\text { objectives }\end{array}$ & $\begin{array}{l}\text { Analyse the complex system } \\
\text { of contributory factors involved } \\
\text { in road freight transportation }\end{array}$ & $\begin{array}{l}\text { Use of Accimap to illustrate the } \\
\text { workings of a systems-based } \\
\text { framework for understanding } \\
\text { the cognitive, motivational and } \\
\text { wider systemic factors } \\
\text { contributing to unsafe } \\
\text { behaviour at level crossings }\end{array}$ \\
\hline $\begin{array}{l}\text { Theoretical } \\
\text { background }\end{array}$ & $\begin{array}{l}\text { Sociotechnical systems } \\
\text { theory; Rasmussen's risk } \\
\text { management framework } \\
\text { (1997) }\end{array}$ & $\begin{array}{l}\text { Sociotechnical systems theory; } \\
\text { Rasmussen's risk management } \\
\text { framework (1997) }\end{array}$ \\
\hline
\end{tabular}


Table 3: Applying the framework to the 26 studies

\begin{tabular}{|c|c|c|}
\hline & 25 & 26 \\
\hline & Newman and Goode (2015) & Stefanova et al (2015) \\
\hline Procedure & $\begin{array}{l}\text { Five stages involving } \\
\text { qualitative coding - three } \\
\text { analysts: (1) identifying } \\
\text { contributory factors and } \\
\text { relationships between them; } \\
\text { (2) factors were then } \\
\text { aggregated using thematic } \\
\text { analysis - Braun and Clarke, } \\
\text { 2006); (3) two researchers } \\
\text { reviewed the coding template; } \\
\text { and, (5) two research } \\
\text { independently classified the } \\
\text { themes according to the } \\
\text { Accimap framework and } \\
\text { resolved disagreements }\end{array}$ & No explicit details \\
\hline Outcomes & $\begin{array}{l}\text { Aggregate Accimap of } \\
\text { contributory factors leading to } \\
\text { road freight transportation } \\
\text { crashes and inter-relationships } \\
\text { between the factors }\end{array}$ & $\begin{array}{l}\text { Two Accimaps: (1) illustration } \\
\text { of crossing context where a } \\
\text { pedestrian commits a violation } \\
\text { s on their way home after } \\
\text { shopping; (2) illustration of } \\
\text { crossing context where a } \\
\text { pedestrian receives a fine for a } \\
\text { violation on their way to work. }\end{array}$ \\
\hline
\end{tabular}


Table 3: Applying the framework to the 26 studies

\begin{tabular}{|c|c|c|}
\hline & 25 & 26 \\
\hline & Newman and Goode (2015) & Stefanova et al (2015) \\
\hline $\begin{array}{l}\text { Comparison } \\
\text { with other } \\
\text { models }\end{array}$ & None & None \\
\hline $\begin{array}{l}\text { Levels of } \\
\text { analysis }\end{array}$ & $\begin{array}{l}6 \text { levels: } \\
\text { Government bodies/ } \\
\text { Regulatory Bodies/Other } \\
\text { organisations and clients/ } \\
\text { Heavy vehicle companies/ } \\
\text { Drivers and other actors at the } \\
\text { scene of the incident/ } \\
\text { Equipment, surroundings and } \\
\text { meteorological conditions }\end{array}$ & $\begin{array}{l}6 \text { levels: } \\
\text { Government/ Regulatory } \\
\text { Bodies/Local Government/ } \\
\text { Technical and Operational } \\
\text { Management/ } \\
\text { Pedestrian level/ } \\
\text { Equipment and Surroundings }\end{array}$ \\
\hline $\begin{array}{l}\text { Causal } \\
\text { factors }\end{array}$ & 60 factors & $\begin{array}{l}\text { Accimap } 1 \text { (19 factors), } \\
\text { Accimap } 2 \text { (20 factors) }\end{array}$ \\
\hline
\end{tabular}


Table 3: Applying the framework to the 26 studies

\begin{tabular}{|l|l|l|}
\hline \multicolumn{1}{|c|}{25} & \multicolumn{1}{|c|}{26} \\
\hline $\begin{array}{l}\text { Changes to } \\
\text { standard } \\
\text { Accimap }\end{array}$ & $\begin{array}{l}\text { Addition of different levels of } \\
\text { analysis }\end{array}$ & $\begin{array}{l}\text { Replacement of 'Physical } \\
\text { Processes and Actor Activities' } \\
\text { with Pedestrian level' }\end{array}$ \\
\hline Other details & $\begin{array}{l}\text { Attempt to test some of the } \\
\text { 'predictions' made by } \\
\text { Rasmussen's (1997) Risk } \\
\text { Management Framework }\end{array}$ & $\begin{array}{l}\text { Accimaps used to provide } \\
\text { support for a new framework }\end{array}$ \\
\hline & & \\
\hline
\end{tabular}


Table 4: Requirements for methods for accident investigation and analysis (Ryan, 2015, p. 827, based on Katsakiori et al., 2009; Sklet, 2004; and, Wagenaar and van der Schrier, 1997)

\section{An accident analysis method should}

1. Have a clear scope for analysis (e.g., whether it should focus at the level of the work and the technological system, or more broadly at influences from government and regulators)

2. Be influenced by a model or group of models

3. Provided a detailed description of the accident, including a visual representation of the accident sequence if appropriate

4. Search for and reveal underlying causes

5. Contribute to understanding of prevention (e.g., safety barriers)

6. Help in generating recommendations

7. Give consideration to practical aspects, such as level of education and training that is needed to use the method

8. Be valid and reliable 